
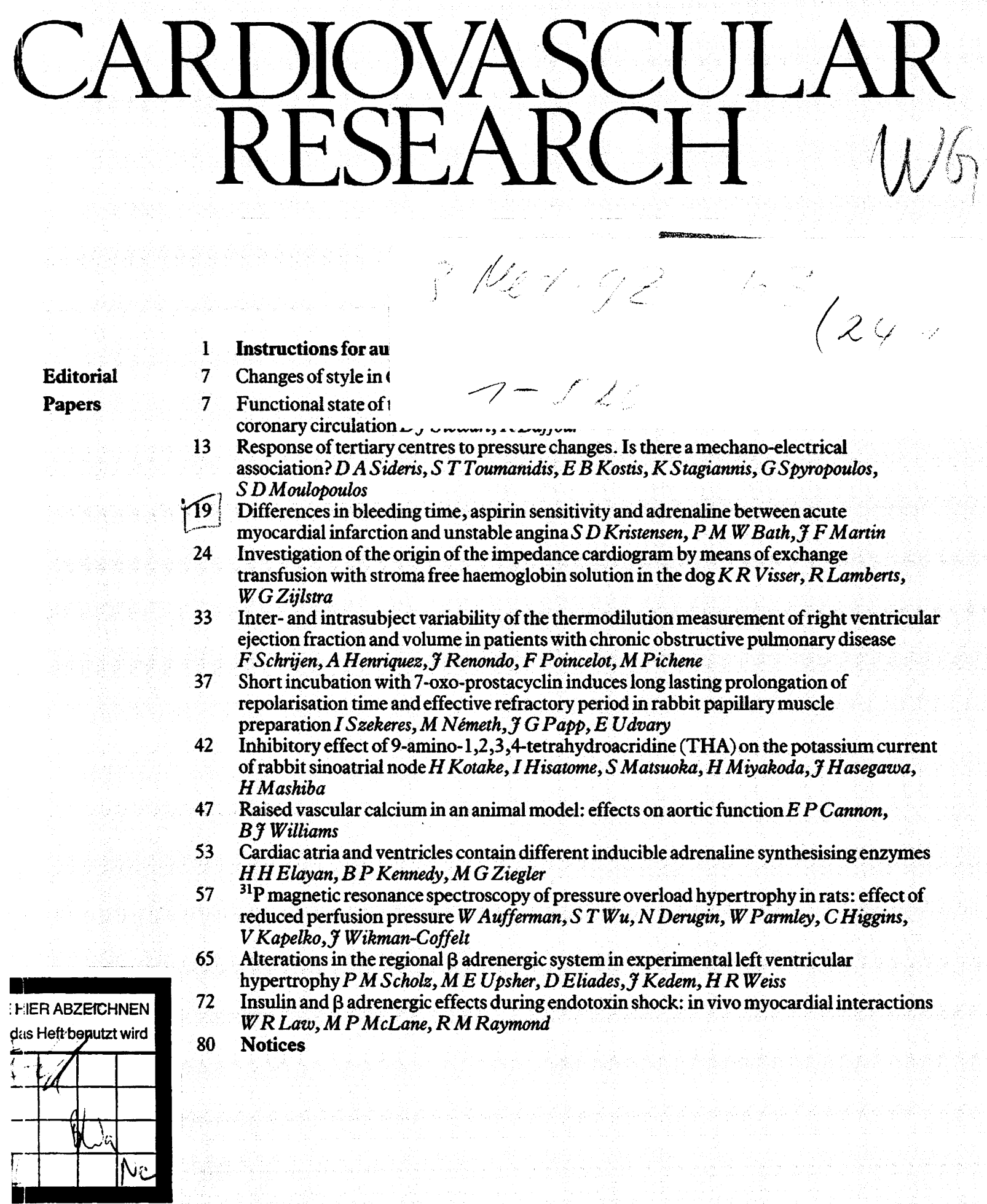


\section{CARDIOVASCULAR RESEARCH}

Published monthly in association with the British Cardiac Society

Editor: P Sleight

Assistant Editors: D H Bergel, T Powell

Technical Editor: O G Brooke

Editorial Committee

H Aars (Norway)

J O Arndt (W Germany)

$\mathrm{GC}$ van den Bos (Netherlands)

J D Bristow (USA),

N L Browse (UK)

\author{
S M Cobbe (UK) \\ PCummins (UK) \\ P H Fentem(UK) \\ $P$ Foëx (UK) \\ W Kübler(W Germany)
}

\author{
G Mancia (Italy) \\ J M Marshall (UK) \\ R Palmer (UK) \\ J R Parratt (UK) \\ P Peronneau (France)
}

\author{
P A Poole-Wilson (UK) \\ A E G Raine (UK) \\ R S Reneman (Netherliards) \\ D H Williamson (UK) \\ $\mathrm{N}$ Woolf $(\mathrm{UK})$
}

Cardiovascular Research is a journal concerned with the link between the basic sciences, clinical physiology and clinical cardiology. Thus its purpose is to provide a forum for those engaged in the application of methods of the basic sciences to the understanding of clinical disease. The formulation of animal models of disease constitutes an important and major area of interest, but not to the exclusion of other subjects. Papers on clinical topics or having a wholly basic scientific content will be accepted, as will review articles on topics of current interest or disease processes. The only criteria for acceptance will be relevance to cardiovascular topics and scientific quality.

Submission of a paper will be held to imply that it ontains original work which has not been published before and isllnet being submitted for publication elsewhere. Permission to repm duce in whole or in part must be obtained from the publishef.

Contributors should send two copies of the text, refefences tables, and figures. Manuscripts must be typewritten, on one side of the paper in double space with wide margins. The following information should be given on a single separate sheet: (1) title and a short title for the running head; (2) authors' names and affiliations; (3) department in which the work was done. Footnotes, on the same sheet, should list: (i) the authors' present addresses if different from the departments in which the work was done; (ii) name and address of author to whom correspondence and reprint requests should be addressed; (iii) receipt of grants. A concise and informative structural abstract should be provided.

Correspondence Letters containing critical assessments of material published in Cardiovascular Research, including reviews, will be considered for publication. They should be sent to the Editor within 6 months of the appearance of the article concerned.

Rapid publication Short papers will be considered for rapid publication (within 3 months). These should contain material which merits accelerated publication and must not occupy more than 4 journal pages, including tables, figures and references (authors are responsible for assessing the length accurately before submission). Current standard section headings should be used. Abstracts should not exceed 100 words, and there should not be more than 10 references. Papers submitted for rapid publication should be clearly marked as such. Rejection does not preclude resubmission as a full paper. No proofs will be sent, so the submitted copy must be entirely correct.

Instructions to authors. These are printed in full annually in the January issue. The following should act as a guide, but authors are urged to consult the full instructions as papers that do not comply will be returned for revision.

SI Units All units of measurement, except for blood pressures, should be in SI (including those in the figures). Blood pressures should be expressed in $\mathrm{mm} \mathrm{Hg}$.

References should be typed (double spacing) on separate sheets. Contributors are responsible for the accuracy of their references.
The numerical system is used, and references should appear in the numerical order in which they are first cited in the text anid should be in the Vancouver style. Journal titles should be abbrevviated in accordance with the style of Index Medicus.

Illustrations Half tones should be presented as unmounted, glossy prints and should be clearly identified on the back of the photograph. Photocopies of line drawings are acceptable.. Figures should be numbered consecutively in Arabic numerals. Legends should be typed (double spacing) on separate sheets.. Colour illustrations can be reproduced at the author's cost.

Tables should be typed on separate sheets and numbered consecutivel in Roman numerals. Tables should be kikept to a Onfintupur. Material which is not subsequently commented upon ing the thould not be included in the tables.

i'Pinofis: Prooks will be sent to the author (except fior rapid communicatibns). Corrections other than printer's errors may be charged to the author.

Reprints Reprints are available on payment of the necesisary costs if they are ordered when the proof is returned.

Notice to advertisers Applications for advertisement space and rates should be made to the Advertisement Manager, Cardiovascular Research, BMA House, Tavistock Square, London WClH 9JR.

\section{Notice to subscribers}

Cardiovascular Research is published monthly. The aninual subscription rates are $£ 129$ inland and $£ 153$ overseas (USA $\$ 248$ ). Combined rate: British Heart fournal \& Cardiovascular-Research $£ 200$ inland and $£ 233$ overseas (USA \$385). Orders should be sent to the Subscriptions Manager, Cardiovascular Research, BMA House, Tavistock Square, London WC1H 9JR. Order:s can also be placed with any leading subscription agent or bookseller. (For the convenience of readers in the USA, subscription orders, with or without payment, may also be sent to: British Medicall fournal, Box 560B, Kennebunkport, Maine 04046. Inquiriies must, however, be addressed to the publisher in London. Alli inquiries regarding air mail rates and single copies already published should be addressed to the publisher in London. Application to mail at second class postage rate is pending at Rahway NJ Postmaster. Send address changes to: Cardiovascular Research, c/o Mercury Airfreight International Ltd Inc, 2323 Randolph Avenue, Avenel, NJ 07001, USA.)

Copyright (C) 1990 by Cardiovascular Research.

All rights reserved. No part of this publication may be reproduced, stored in a retrieval system or transmitted in any form, or by any means, electronic, mechanical, photocopying, recording or otherwise, without the prior permission of the copyright owners.

Papers for publication should be sent to the Editor, Cardiovascular Research, c/o University Department of Physiology, Parks Road, Oxford OX1 3PT. Queries about submitted manuscripts should be addressed to Miss Christine Lake, at the above address (Tel: 0865 310691; FAX 0865 272469). Address queries about accepted manuscripts to Dr Oliver Brooke, 49 Rusholme Rd, London SW15 3LF (Tel: 01 788 2228). The Editor does not accept responsibility for damage to or loss of papers submitted. 


\section{CONTENTS}

No 1 JANUARY 1990

Instructions to authors

Functional state of the endothelium determines the response to endothelin in the coronary circulation: Duncan J Stewart, Richard Baffour

Response of tertiary centres to pressure changes. Is there a mechano-electrical association? Dimitris A Sideris, Savvas T Toumanidis, Evangelos B Kostis, Konstantinos Stagiannis, George Spyropoulos, Spyridon D Moulopoulos

Differences in bleeding time, aspirin sensitivity and adrenaline between acute myocardial infarction and unstable angina: Steen D Kristensen, Philip $M W$ Bath, John F Martin

Investigation of the origin of the impedance cardiogram by means of exchange transfusion with stroma free haemoglobin solution in the dog: Klaas $R$ Visser, Robert Lamberts, Willem G Zijlstra

Inter- and intrasubject variability of the thermodilution measurement of right ventricular ejection fraction and volume in patients with chronic obstructive pulmonary disease: F Schrijen, A Henriquez, J Renondo, F Poincelot, M Pichene

Short incubation with 7-oxo-prostacyclin induces long lasting prolongation of repolarisation time and effective refractory period in rabbit papillary muscle preparation: L Szekeres, M Németh, J G Papp, Eva Udvary

Inhibitory effect of 9-amino-1,2,3,4-tetrahydroacridine (THA) on the potassium current of rabbit sinoatrial node: Hiroshi Kotake, Ichiro Hisatome, Satoshi Matsuoka, Hiroyuki Miyakoda, Junichi Hasegawa, Hiroto Mashiba .

Raised vascular calcium in an animal model: effects on aortic function: Elizabeth $P$ Cannon, Betty J Williams

Cardiac atria and ventricles contain different inducible adrenaline synthesising enzymes: $\mathrm{H} \mathrm{H}$ Elayan, B P Kennedy, $M$ G Ziegler .

${ }^{31} \mathrm{P}$ Magnetic resonance spectroscopy of pressure overload hypertrophy in rats: effect of reduced perfusion pressure: Wolfgang Aufferman, Shao T Wu, Nikita Derugin, William Parmley, Charles Higgins, Valeri Kapelko, Joan WikmanCoffelt

Alterations in the regional $\beta$ adrenergic system in experimental left ventricular hypertrophy: Peter M Scholz, Mary E Upsher, Diane Eliades, Joseph Kedem, Harvey $\mathrm{R}$ Weiss

Insulin and $\beta$ adrenergic effects during endotoxin shock: in vivo myocardial interactions: William R Law, Michael P McLane, Richard M Raymond .

\section{No 2 FEBRUARY 1990}

Effect of hyper- and hypovolaemia on regional myocardial oxygen consumption: P M Scholz, J Kedem, S Sideman, R Beyar, H R Weiss.

Induction of the heat shock response in rats modulates heart rate, creatine kinase and protein synthesis after a subsequent hyperthermic treatment: $R$ William Currie, Brenda M Ross, Trudy A Davis . 
Alterations in polyunsaturated fatty acid composition of cardiac membrane phospholipids and $\alpha_{1}$ adrenoceptor mediated phosphatidylinositol turnover: Johanna T A Meij, Alessandra Bordoni, Dirk H W Dekkers, Carlo Guarnieri, Jos M J Lamers

Plasma neuropeptide $Y$ on admission to a coronary care unit: raised levels in patients with left heart failure: Johan Hulting, Alf Sollevi, Bengt Ullman, Anders Franco-Cereceda, Jan $M$ Lundberg .

Effect of early reperfusion on use of triphenyltetrazolium chloride to differentiate viable from non-viable myocardium in area of risk: Israel Freeman, Andrew $M$ Grunwald, Bruce Robin, P S Rao, Monty M Bodenheimer

Verification of a canine model of transient exercise induced myocardial dysfunction: antianginal effects of flestolol, an ultra short acting $B$ adrenoceptor antagonist: Georg Fischer, Joseph G Grohs, Gerhard Raberger

Training in dogs with normal coronary arteries: lack of effect on collateral development: Michael V Cohen

Pulsatile flow and oscillating wall shear stress in the brachial artery of normotensive and hypertensive subjects: Alain C Simon, Jaime Levenson, Patrice Flaud

Effects of antihypertensive drugs on heart and resistance vessels: Hideo Kobayashi, Toshio Sano, Robert C Tarazi, Fetnat M Fouad-Tarazi .

Cumene hydroperoxide, an agent inducing lipid peroxidation, and 4-hydroxy-2,3nonenal, a peroxidation product, cause coronary vasodilatation in perfused rat hearts by a cyclic nucleotide independent mechanism: A $M M$ van der Kraaij, H R de Jonge, $H$ Esterbauer, J de Vente, $H$ W M Steinbusch and J F Koster .

Influence of reflow ventricular fibrillation and electrical defibrillation on infarct size in a canine preparation of myocardial infarction: Michel de Lorgeril, Arsène Basmadjian, Robert Clément, Guy Rousseau, Jean-Gilles Latour

Reperfusion damage: free radicals mediate delayed membrane changes rather than early ventricular arrhythmias: William A Coetzee, Patricia Owen, Steven C Dennis, Selva Saman, Lionel H Opie

Rapid communication:

Effect of blood viscocity on arterial flow induced dilator response: Arthur $M$ Melkumyants, Sergey A Balashov

No 3 MARCH 1990

Effect of prolonged hypothermic ischaemia on myocardial sarcoplasmic reticular calcium transport: Kohji Fukumoto, Hitoshi Takenaka, Yasunori Koga, Minoru Hamada

Effects of haemorrhage induced hyptension on coronary blood flow in an anaesthetised two vessel canine coronary stenosis-occlusion model: Joseph A Gascho, John H Lawrence, George A Beller

Negative inotropic effects of amiodarone on isolated guinea pig papillary muscle: Masahiro Aomine, Donald H Singer

Combined inhibitory effects of aspirin and ethanol on adrenaline exacerbation of acute platelet thrombus formation in stenosed canine coronary arteries: Jeffery W Keller, John D Folts . 
Effects of chronic glyceryl trinitrate on left ventricular haemodynamics in a rat model of congestive heart failure: demonstration of a simple animal model for the study of in vivo nitrate tolerance: John Anthony Bauer, Ho-Leung Fung .

Compensated function in hypertrophied ventricles of Wistar Kyoto and spontaneously hypertensive rats: Robert J Tomanek, Mary $\mathrm{T}$ Whitaker.

Circadian variation of heart rate variability: Simon C Malpas, Gordon L Purdie.

Non-invasive continuous finger blood pressure measurement during orthostatic stress compared to intra-arterial pressure: Ben P M Imholz, Jos J Settels, Anton $\mathrm{H}$ van der Meiracker, Karel H Wesseling, Wouter Wieling

Increased sensitivity to isoprenaline following digoxin pretreatment in anaesthetised and conscious dogs: Anastasia S Mihailidou, Rosemarie Einstein, Desmond P Richardson, Peter Gray, Michael P Jones, Stephen N Hunyor

Effects of anaesthesia on acute ischaemic arrhythmias and epicardial electrograms in the pig heart in situ: Alfredo Bardaji, Juan Cinca, Fernando Worner, Antonio Schoenenberger

Cellular electrophysiological effects of flecainide on human atrial fibres: Bruno Le Grand, Jean-Yves Le Heuzey, Patrick Perier, Pierre Peronneau, Thomas Lavergne, Stéphane Hatem, Louis Guize

Improved cardiac performance with human calcitonin gene related peptide in patients with congestive heart failure: C Gennari, R Nami, D Agnusdei, J A Fischer

Release of neuropeptide $\mathrm{Y}$ and noradrenaline from the human heart after aortic occlusion during coronary artery surgery: Anders Franco-Cereceda, Anders Öwall, Göran Settergren, Alf Sollevi, Jan M Lundberg

Beneficial effect of adenosine during reperfusion following prolonged cardioplegic arrest: Simon Ledingham, Osamu Katayama, David Lachno, Naina Patel, Magdi Yacoub .

Left ventricular length dependent activation in the isovolumetric rat heart: Ivanita Stefanon, Dalton Valentim Vassallo, José Geraldo Mill

No 4 APRIL 1990

Sulphinpyrazone reduces endocardial injury and mural thrombosis: Glenn Carter, John B Gavin

Inverse relationship between ESR spin trapping of oxyradicals and degree of functional recovery during myocardial reperfusion in isolated working rat heart: Ingolf E Blasig, Bernd Ebert, Carmen Hennig, Tibor Pali, Arpad Tosaki .

Importance of myocardial ischaemia for recruitment of coronary collateral circulation in dogs: Kazuto Yamanishi, Masatoshi Fujita, Akira Ohno, Shigetake Sasayama

Morphometry of the small arteries and arterioles in the rat heart: effects of chronic hypertension and exercise: Karel Rakusan, Pierre Wicker

Acute pulmonary microembolism induces different regional changes in preload and contraction pattern in canine right ventricle: Bernhard Zwissler, Helmuth Forst, Konrad Messmer .

Electrophysiological effects of acetylcholine in Purkinje fibres surviving infarction: Antoine Bril, Ricky Y K Man 
Mechanism of ECG changes and arrhythmogenic properties of low osmolality contrast media during coronary arteriography in dog: Nils-Einer Kløw, Pål M Tande, Olav Hevrøy, Helge Refsum

Electrophysiological changes in animal model of chronic cardiac failure: John D Doherty, Stuart M Cobbe

Uptake of radioiodinated cardiac specific troponin-I antibodies in myocardial infarction: Bernadette Cummins, Geoffrey J Russell, Stephen T Chandler, David J Pears, Peter Cummins

Optimised function for determining time to peak creatine kinase and creatine kinase-MB as non-invasive reperfusion indicators after thrombolytic therapy in acute myocardial infarction: Holger Schwerdt, Cem Özbek, Gerd Fröhlig, Hermann Schieffer, Ludwig Bette.

Sympathectomy alters acetylcholinesterase expression in adult rat heart: Cynthia Nyquist Battie, Nancy Moran

A new experimental model for measurement of pulmonary arterial haemodynamic variables in conscious rats before and after pulmonary embolism and during general anaesthesia: Günter A J Riegger, Peter Hoferer .

No 5 MAY 1990

Action of endogenous atrial natriuretic peptide in calves with experimental acute central venous congestion and low cardiac output: Alexander M Rokitansky, Udo M Losert, W Trubel, G Wieselthaler, Sybille Krausler, W Shreiner, P Buxbaum, H Vierhapper, W K Waldhäusl, E Wolner

Atrial natriuretic peptides in canine hypoxic pulmonary vasoconstriction: JeanLuc Vachiery, Philippe Lejeune, Roger Hallemans, Serge Brimioulle, MarieFrance Debiève, Maurice Abramow, Robert Naeije .

Coronary zero flow pressure and intramyocardial pressure in transiently arrested heart: Shoichi Satoh, Yukio Maruyama, Jun Watanabe, Mitsumasa Keitoku, Katsuyuki Hangai, Tamotsu Takishima .

Self suppression of phosphoinositide turnover and contraction by stimulating release of endogenous endothelium derived relaxing factor in vascular action of histamine: Takashi Nishimoto, Mitsuhiro Yokoyama, Hisashi Fukuzaki .

Effect of posture on spontaneous and thermally stimulated cardiovascular oscillations: Ari Lindqvist, Jarmo Jalonen, Pekka Parviainen, Kari Antila, Lauri A Laitinen

Chronic diabetes mellitus prolongs action potential duration of rat ventricular muscles: circumstantial evidence for impaired $\mathrm{Ca}^{2+}$ channel: Seike Nobe, Masahiro Aomine, Makoto Arita, Sukenobu Ito, Ryosaburo Takaki .

Changes in the microcirculation in slow and fast skeletal muscles with long term limitations of blood supply: Judith M Dawson, Olga Hudlicka

Antianginal drugs and relationship between epicardial ST segment depression and moderate regional myocardial blood flow reduction in experimental partial coronary artery occlusion: George B Timogiannakis, Constantin B Kourouklis, Emmanuel N Chlapoutakis, Paul K Toutouzas

Attenuation of the rise in extracellular potassium concentration during myocardial ischaemia by d.1-sotalol and d-sotalol: $M \mathrm{~N}$ Hicks, S M Cobbe 
Control of mitochondrial ATP synthase in heart cells: inactive to active transitions caused by beating or positive inotropic agents: Anibh $M$ Das, David A Harris

Heat production by the human left ventricle: measurement by a thermodilution technique: James T Stewart, Huon H Gray, Christopher Calicott, Roy E Smith, A John Camm

Relationship between bioimpedance, thermodilution, and ventriculographic measurements in experimental congestive heart failure: Francis $G$ Spinale, David A Hendrick, Fred A Crawford, Blase A Carabello .

Simple, rapid, and effective method of producing aortocaval shunts in the rat: Raul Garcia, Suzanne Diebold

Effects of acutely impaired regional function on remote myocardial wall motion and blood flow in the canine left ventricle studied by coronary occlusion and hypoxic perfusion: Sadanori Ohtsuka, Masaaki Kakihana, Toshiki Doi, Yasuro Sugishita, Iwao Ito .

Adenine nucleotide depletion and contractile dysfunction in the "stunned" myocardium: Riccardo Zucchi, Ugo Limbruno, Antonio Di Vincenzo, Mario Mariani, Giovani Ronca

Quantitative ultrasonic assessment of normal and ischaemic myocardium with an acoustic microscope: relationship to integrated backscatter: Kiran B Sagar, Diane H Agemura, William D O'Brien Jr, Lorie R Pelc, Theodore L Rhyne, L Samuel Wann, Richard A Komorowski, David C Warltier

Selective ECG synchronised suction and retroinfusion of coronary veins: first results of studies in acute myocardial ischaemia in dogs: Peter Boekstegers, Joachim Diebold, Christoph Weiss .

Inhibition of acute platelet thrombosis formation in stenosed canine coronary arteries by specific serotonin $\mathbf{5 H T}_{2}$ receptor antagonist ritanserin: Sheryl Torr, Mark I M Noble, John D Folts

Effects of streptokinase, urokinase, and recombinant tissue plasminogen activator on platelet aggregability and stability of platelet aggregates: Wolfram Terres, Stefan Umnus, Detlaf G Mathey, Walter Bleifeld

The area ratio of normal arterial junctions and its implications in pulse wave reflections: George L Papageorgiou, Barrie N Jones, Vincent J Redding, Norah Hudson .

Collateral bronchopulmonary circulation after spontaneous recanalisation of pulmonary thromboemboli in the dog: Jozef Jandik, Eva Řehulvá, Jiři Endrys, Hilaire De Geest

Hydrogen peroxide induced changes in membrane potentials in guinea pig ventricular muscle: permissive role of iron: Ludwik Firek, Andrzej Beresewicz

Recombinant human extracellular superoxide dismutase reduces concentration of oxygen free radicals in the reperfused rat heart: Mats $\mathrm{H}$ Johansson, Johanna Deinum, Stefan L Marklund, Per-Ove Sjöquist 
Measurement of microvascular permeability to small solutes in man: limitations of the technique: A $M$ Peters

Calcium inhibition of glycolysis contributes to ischaemia injury: Wolfgang Auffermann, Stefan Wagner, Shao Wu, Peter Buser, William W Parmley, Joan Wikman-Coffelt

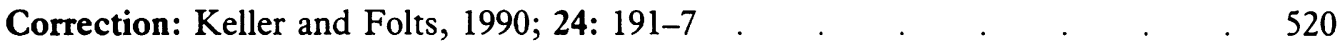

Notices

\section{No 7 FULY 1990}

Effects of long term metoprolol administration on the electrocardiogram of rats infected with $T$ cruzi: Reinaldo B Bestetti, Vicente N Sales-Neto, Lucimara Z Pinto, Edson Garcia Soares, Gerson Muccillo, J Samuel M Oliveira .

Assessment of cellular viability in cardiovascular tissue as studied with ${ }^{3 \mathbf{H}}$ proline

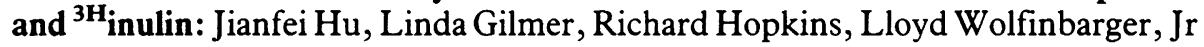

Endogenous adenosine vagal negative chronotropic effect during hypoxia in the anaesthetised rabbit: Giuseppe Verlato, Piet Borgdorff

Reduced heart lipid peroxidation precedes cardiac dilatation in turkeys with naturally occurring cardiomyopathy: Daniela Lax, Shu-Lun Zhang, Ying Li, Lee Williams, Nancy A Staley, George R Noren, Stanley Einzig

Isoenzyme profiles of creatine kinase, lactate dehydrogenase, and aspartate aminotransferase in the diabetic heart: comparison with hereditary and catecholamine cardiomyopathies: Yoshifumi Awaji, Hidekazu Hashimoto, Yoshichika Matsui, Katsuhiro Kawaguchi, Kenji Okumura, Takayuki Ito, Tatsuo Satake

Oxygen and extracellular fluid restriction in cultured heart cells: electron microscopy studies: Zvi Ne'eman, Arié Pinson

Evaluation of transmitral pressure gradients at different heart rates: divergent action of isoprenaline and atropine: Peter Carmeliet, André Aubert, Frans Van de Werf, Hilaire De Geest

Pathophysiological role of changing atrial size and pressure in modulation of atrial natriuretic factor during evolving experiment heart failure: Gordon W Moe, Carmella Angus, Robert J Howard, Adolfo J De Bold, Paul W Armstrong

Expression of fibrillar types I and III and basement membrane collagen type IV genes in myocardium of tight skin mouse: Douglas Chapman, Mahboubeh Eghbali .

Calcium sensitivity of isometric tension in intact papillary muscles and chemically skinned trabeculae in different models of hypertensive hypertrophy: Pablo Pedroni, Gustavo N Perez, Alicia Mattiazzi

Chronic doxorubicin induced cardiomyopathy in rabbits: mechanical, intracellular action potential, and $\beta$ adrenergic characteristics of the failing myocardium: Hossein Shenasa, Angelino Calderone, Michel Vermeulen, Pierre Paradis, Heather Stephens, René Cardinal, Jacques de Champlain, Jean L Rouleau

Rapid Communication:

Heterogeneity in cellular response and intracellular distribution of $\mathrm{Ca}^{2+}$ concentration during and after metabolic inhibition: Hideharu Hayashi, Haruo Miyata, Akira Kobayashi, Noboru Yamazaki 
Intracoronary adenosine causes angina pectoris like pain - an inquiry into the nature of visceral pain: Bo Lagerqvist, Christer Sylvén, Björn Beermann, Gunnar Helmius, Anders Waldenström

Different histamine actions in proximal and distal human coronary arteries in vitro: Mitsumasa Keitoku, Yukio Maruyama, Tamotsu Takishima

Non-invasive evaluation of segmental pressure drop and resistance in large arteries in humans based on a Poiseuille model of intra-arterial velocity distribution: Alain Ch Simon, Patrice Flaud, Jaime Levenson .

Cardiac baroreflex function during postural change assessed using non-invasive spontaneous sequence analysis in young men: Andrew Steptoe, Claus Vögele

Effect of acute cardiac tamponade on left ventricular pressure-volume relations in anaesthetised dogs: William E Johnston, Jakob Vinten-Johansen, H Sidney Klopfenstein, William P Santamore, William C Little

Remodelling of left ventricle after banding of ascending aorta in the rat: Mitsuhide Imamura, Mark Schluchter, Fetnat M Fouad-Tarazi

Cardiac muscle function following chronic dietary potassium depletion in the rabbit: Jeremy P T Ward

Antiarrhythmic effect of amiodarone on doxorubicin acute toxicity in working rat hearts: Chantal Lambert, Claude Mossiat, Marianne Tannière-Zeller, Véronique Maupoil, Luc Rochette.

Effect of activation sequence on ventricular refractoriness as determined by extrastimuli: Nicholas J Linker, Mark Dancy, Marek Malik, Susan Jones, David E Ward

Loss of blood platelet adhesion after heating native and cultured human subendothelium to $100^{\circ}$ Celcius: Cornelius Borst, Anke N Bos, Jaap J Zwaginga, Rienk Rienks, Philip G de Groot, Jan J Sixma

Effects of the free radical generating system $\mathrm{FeCl}_{3} / \mathrm{ADP}$ on reperfusion arrhythmias of rat hearts and electrical activity of canine Purkinje fibres: Antoine Bril, Luc Rochette, Alain Verry, Véronique Maupoil, Ricky Y K Man, Lionel H Opie

Photoactivation of porphyrins: studies of reactive oxygen intermediates and arrhythmogenesis in the aerobic rat heart: Yoshiki Kusama, Michèle Bernier, David J Hearse

Nisoldipine inhibits lipid peroxidation induced by coronary occlusion in pig myocardium: Krystyna Herbaczynska-Cedro, Wanda Gordon-Majszak

Occlusion time dependency of regional noradrenaline release and cardiac arrhythmias during reperfusion of acutely ischaemic heart in the dog in vivo. Nobuharu Yamaguchi, Tomohiko Kimura, Daniel Lamontagne, Jacques de Champlain, Reginald Nadeau .

688

Notices

\section{No 9 SEPTEMBER 1990}

Enhanced myocardial salvage by maintenance of microvascular patency following initial thrombolysis with recombinant tissue plasminogen activator: David J Longridge, Michael J Follenfant, Miles P Maxwell, Alison J Ford, Bernadette Hughes. 
Increased vasoconstrictor response to noradrenaline in femoral vascular bed of diabetic dogs. Is thromboxane $\mathbf{A}_{2}$ involved? Mária Zsófia Koltai, Peter Rösen, György Ballagi-Pordány, Pál Hadházy, Gábor Pogátsa

Flow motion waves with high and low frequency in severe ischaemia before and after percutaneous transluminal angioplasty: Ulrich Hoffmann, Ernst Schneider, Alfred Bollinger

Effects of nifedipine on systemic hydraulic vascular load in patients with hypertension: Kuo-Chu Chang, Kai-Shen Hsieh, Te-Son Kuo, Hsing I Chen .

Determination of effective and safe dose for intracoronary administration of nicorandil in dogs: Shoji Kojima, Shirou Ishikawa, Kazunori Ohsawa, Hidezo Mori

Indomethacin suppresses the coronary flow response to hypoxia in exercise trained and sedentary rats: T S Baur, G R Brodowicz, D R Lamb .

Capillary permeability of ${ }^{131} \mathrm{I}$-albumin in the resting human forearm: William $\mathrm{P}$ Paaske, Ole Henriksen, Per Sejrsen

Reactive and reparative fibrillar collagen remodelling in the hypertrophied rat left ventricle: two experimental models of myocardial fibrosis: Marc S Silver, Ruth Pick, Christian G Brilla, Jorge E Jalil, Joseph S Janicki, Karl T Weber

Changes in performance of the surviving myocardium after left ventricular infarction in rats: José Geraldo Mill, Ivanita Stefanon, Cláudia M Leite, Dalton V Vassallo .

Sympathomimetic amines and cardiac arrhythmias: E Oppenheimer, E Akavia, S Shavit, A D Korczyn

Influence of electrogenic $\mathrm{Na} / \mathrm{Ca}$ exchange on the action potential in human heart muscle: Vincent J A Schouten, Henk E D J ter Keurs, Jan M Quaegebeur

Effects of increased pericardial pressure on the coupling between the ventricles: William P Santamore, Kun S Li, Takaaki Nakamoto, William E Johnston

\section{No 10 OCTOBER 1990}

Systolic thickening increases from subepicardium to subendocardium: Joseph A Gascho, Gary L Copenhaver, Daniel F Heitjan

Electrophysiological effects of a chemical defibrillatory agent, dibenzepin: Giora Amitzur, Nabil El-Sherif, William B Gough

Ischaemically induced alterations in electrical activity and mechanical performance of isolated blood perfused canine myocardial preparations: Norio Himori, Allen P Walls, Allan M Burkman.

Significance of long term components of heart rate variability for the further prognosis after acute myocardial infarction: Marek Malik, A John Camm

Improvement of diagnosis in the non-invasive assessment of coronary artery disease: enhanced evaluation of quantitative exercise ${ }^{201}$ thallium imaging by multivariate analysis: Menco G Niemeyer, Aelko $\mathrm{H}$ Zwinderman, Maarten J Cramer, Ernst E van der Wall, Fred J Verzijlbergen, Arno Breeman, Carl A Ascoop, Ernest K J Pauwels

Importance of vasomotor tone to myocardial function and regional metabolism during constant flow ischaemia in swine: Edward O McFalls, George A Pantely, Cheryl G Anselone, David J Bristow 
Changes in blood pressure during isometric contractions to fatigue in the cat after brain stem lesions: effects of clonidine: Carole A Williams, Jon R Roberts, Douglas B Freels

Adriamycin cardiomyopathy in the rabbit: alterations in contractile proteins and myocyte function: S Mary Jones, Mark S Kirby, Sian E Harding, Giorgio Vescova, Richard B Wanless, Luciano Dalla Libera, Philip A Poole-Wilson

Glomerular and vascular atrial natriuretic factor receptors in cardiomyopathic hamsters: correlation with the peptide biological effects: Victorio Cachofeiro, Ernesto L Schiffrin, Marc Cantin, Raul Garcia

Effect of left intraventricular pressure on magnitude of vascular waterfall in the epicardial coronary veins: Raúl J Domenech, Pilar Macho, Felipe Barros

Species differences in vulnerability to injury by oxident stress: a possible link with calcium handling? Tomoaki Nakata, David J Hearse

Notice

\section{No 11 NOVEMBER 1990}

Regional pulse wave velocities in hypertensive and normotensive humans: $\mathrm{C} T$ Ting, M S Chang, S P Wang, B N Chiang, Frank C P Yin

Intracellular $\mathrm{pH}$ nd role of $\mathrm{Na}^{+} / \mathrm{H}^{+}$exchange during ischaemia and reperfusion of normal and diabetic rat hearts: Nassirah Khandoudi, Monique Bernard, Patrick Cozzone, Danielle Feuvray

Myocardial ischaemia induced by endothelin in the intact rabbit: angiographic analysis: Ken-ichi Hirata, Yuichi Matsuda, H Akita, M Yokoyama, H Fukuzaki

Interplay between adrenaline and interbeat interval on ventricular repolarisation in intact heart in vivo: Peter Taggart, Peter Sutton, Max Lab, John Dean, Frank Harrison

Effect of pre-existing four hour coronary stenosis on ventricular arrhythmias during a subsequent $\mathbf{1 0}$ minute occlusion in dogs: Masasuke Fujita, Yasuo Nagamoto, Youichirou Furuno, Takashi Ohkita, Akio Kuroiwa

896

Characterisation of decay of frequency induced potentiation and postextrasystolic potentiation: Henk E D J ter Keurs, Wei Dong Gao, Hans Bosker, Angela J Drake-Holland, Mark I M Noble

Positive inotropy linked with class III antiarrhythmic action: electrophysiological effects of the cardiotonic agent DPI 201-106 in the dog heart in vivo: Elin Mortensen, Pål M Tande, Nils-Einar Kløw, Eivind S Platou, Helge Refsum

Taurine depresses $I_{\mathrm{Na}}$ and depolarises the membrane but does not affect membrane surface charges in perfused rabbit hearts: Robert Dumaine, Otto $\mathrm{F}$ Schanne, Elena Ruiz-Petrich .

Combined application of class I antiarrhythmic drug causes "additive", "reductive", or "synergistic" sodium channel block in cardiac muscles: Takashi Kawamura, Itsuo Kodama, Junji Toyama, Hiroshi Hayashi, Hidehiko Saito, Kazuo Yamada

5-Hydroxytryptamine receptor profile in healthy and diseased human epicardial coronary arteries: Adrian $\mathrm{H}$ Chester, Graeme $\mathrm{R}$ Martin, Mikeal Bodelsson, Brigitta Arneklo-Nobin, Samad Tadjkarimi, Kenneth Tornebrandt, Magdi H Yacoub. 
Effect of congestive heart failure on rate of atrial natriuretic factor release in response to stretch and isoprenaline: G Agnoletti, A Cornacchiari, A F Panzali, S Ghielmi, F De Giuli, R Ferrari

Urinary cyclic guanosine monophosphate as an indicator of experimental congestive heart failure in rats: Jean-Baptiste Michel, Jean-Jacques Mercadier, FrançoisXavier Galen, Rémi Urbain, Jean-Claude Dussaule, Monique Philippe, Pierre Corvol

\section{No 12 DECEMBER 1990}

Spontaneous rhythmic contractile behaviour of aortic ring segments isolated from pressure loaded regions of the vasculature: C Roger White, John E Zehr

Cardiovascular responses to graded treadmill exercise during the development of doxorubicin induced heart failure in rabbits: D Langton, B Jover, B P McGrath, J Ludbrook

Evidence for an intrinsic mechanism regulating heart rate variability in the transplanted and the intact heart during submaximal dynamic exercise? Luciano Bernardi, Fabrizio Salvucci, Roberto Suardi, Pier Luigi Soldá, Alessandro Calciati, Stefano Perlini, Colomba Falcone, Lucio Ricciardi

Myocardial pathology in rats exposed to prolonged environmental heat: $\mathrm{R}$ Yarom, E Levy, M Horowitz

Intracoronary endothelin-1 increases coronary retrograde pressure by constricting arterioles: Keiichi Fukuda, Shingo Hori, Masatoshi Kusuhara, Toru Satoh, Shingo Kyotani, Soushin Inoue, Hideto Ohno, Ken Yamaguchi, Shunnosuke Handa, Yoshiro Nakamura

Protective effects of calcium channel blockers on hydrogen peroxide induced increases in endothelial permeability: Yoshiji Yamada, Mitsuhiro Yokota, Taikeo Furumichi, Hirohiko Furui, Kazunobu Yamauchi, Hidehiko Saito

Coronary reactivity in the porcine heart after short lasting myocardial ischaemia: effects of duration of ischaemia and myocardial stunning: Knut Arvid Kirkeböen, Gunnar Aksnes, Arnfinn Ilebekk

On the mode of cardioprotection produced by a new bradycardic agent, FR 76830, during ischaemic and after reperfusion in the isolated perfused rat heart: a ${ }^{31}$ P-NMR study: Takaharu Ishibashi, Taku Matsubara, Mikio Nakazawa, Naoki Katsumata, Shoichi Imai

Protective effects of nipradilol, isosorbide dinitrate, and bunazosin on coronary artery constriction induced by intracoronary injection of acetylcholine in pigs: Atsushi Kawamura, Hisayoshi Fujiwara, Moriharu Ishida, Genzou Takemura, Mitsugu Kida, Takashi Uegaito, Masahiro Tanaka, Chuichi Kawai .

Protective effects of preconditioning of the ischaemic myocardium involve cyclo-oxygenase products: Agnes Vegh, Laszlo Szekeres, James R Parratt 


\title{
Acute pulmonary microembolism induces different regional changes in preload and contraction pattern in canine right ventricle
}

\author{
Bernhard Zwissler, Helmuth Forst, Konrad Messmer
}

\begin{abstract}
Study objective - The aim of the study was to investigate the influence of acute pulmonary embolism on local myocardial preload and contraction pattern in right ventricle.

Design - Measurements of preload and contraction pattern were made in inflow and outflow tracts of canine right ventricular free wall by sonomicrometry. Local right ventricular preload was assessed from end diastolic segment length. Contraction pattern was assessed from pressure-length loops and quantified by calculating maximal, systolic, and postsystolic shortening, and protosystolic segment elongation. Data were obtained before and after microembolisation with $100 \mu \mathrm{m}$ glass beads in combination with oleic acid.

Subjects - 13 foxhounds of either sex were used, weight $20.4 \pm 4.0 \mathrm{~kg}$.

Measurements and main results - Pulmonary microembolisation resulted in a rise in systolic, mean, and end diastolic right ventricular pressure and pulmonary vascular resistance. At the same time, the pressure-length loops, originally triangular or oval, became rectangular in both inflow and outflow tract. Normalised end diastolic segment length increased in the inflow tract from 10.0 to 10.3 $\mathrm{mm}(\mathrm{p}<0.01)$, but simultaneously decreased in the outflow tract, from 10.0 to $9.6 \mathrm{~mm}(\mathrm{p}<0.05)$. Segment shortening in the inflow tract was not affected but deteriorated in the outflow tract from 11.6 to $2.7 \%(\mathbf{p}<0.01)$.
\end{abstract}

Department of Experimental Surgery, University of Heidelberg, Im Neuenheimer Feld 347, 6900 Heidelberg, West Germany

B Zwissler

K Messmer

Department of Anaesthesiology, University of Munich, Klinikum Grosshadern, Munich, West Germany

$\mathrm{H}$ Forst

Correspondence to: Dr Zwissler

Key words: pulmonary microembolism; right ventricle; preload; myocardial contraction; sonomicrometry; pressurelength loops

Submitted 31 Fuly 1989

Accepted 1 November 1989
Conclusions - Increase in afterload due to pulmonary microembolisation caused regionally different changes in local preload and segment shortening in right ventricular free wall. Clinically available measures of global right ventricular preload do not assess these local differences in preload and therefore may fail to reflect the functional state of the right ventricle accurately.

Preload on the right ventricle is known to influence its performance through the Frank-Starling mechanism. ${ }^{\prime 2}$ In critically ill patients with high pulmonary vascular resistance (eg, in acute pulmonary embolism), the role of optimal right ventricular preload for preservation of stroke volume has been recognised..$^{3-7}$ Preload is usually defined as the tension or length of myocardial fibres at end diastole, ${ }^{8}$ the two variables not being measurable under clinical conditions. ${ }^{9}$ As a substitute, indices of right ventricular preload have been derived from measurements of central venous, right atrial, or right ventricular end diastolic pressures and, more recently, by assessing right ventricular filling volume or end diastolic dimensions. ${ }^{10}$ However, all these variables are based on the assumption that changes in ventricular pressure or volume are paralleled by equivalent changes of myocardial end diastolic fibre length in all regions of the right ventricle.

The right ventricle is an irregular crescent shaped chamber surrounded by a concave free wall and a convex interventricular septum. It therefore seems likely that changes in end diastolic pressure or filling volume are not uniformly distributed within the ventricular lumen. ${ }^{11} 12$ If this were true, changes in these variables would not necessarily reflect equivalent changes in myocardial end diastolic tension throughout the various regions of the right ventricular free wall. As a result, local contractile function of myocardial fibres would differ at different locations in the ventricular wall. To analyse this problem, local right ventricular preload and contraction pattern of myocardial segments were studied by means of sonomicrometry in two regions (inflow and outflow tract) of the canine right ventricular free wall, before and after acute pulmonary microembolisation. 


\section{Methods}

The experiments were performed in accordance with the NIH guidelines on the care and use of laboratory animals. Thirteen fox hounds of either sex (weight $20.4 \pm 4.0 \mathrm{~kg}$ ) were used. After premedication with propiomazin 1-1.5 mg $\mathrm{kg}^{-1}$ (Combelen ${ }^{\circledR}$, Bayer, Leverkusen, FRG), anaesthesia was induced by a bolus injection of pentobarbitone $20 \mathrm{mg} \cdot \mathrm{kg}^{-1}$ (Nembutal ${ }^{\circledR}$, Ceva, Segeberg, FRG), piritramid 0.75 $\mathrm{mg} \cdot \mathrm{kg}^{-1}$ (Dipidolor ${ }^{\circledR}$, Janssen, Neuss, FRG) and alcuronium $0.25 \mathrm{mg} \cdot \mathrm{kg}^{-1}$ (Alloferin ${ }^{\circledR}$, Roche. Grenzach-Whylen, FRG) and maintained by continuous infusion of pentobarbitone $5 \mathrm{mg} \cdot \mathrm{kg}^{-1} \cdot \mathrm{h}^{-1}$. Additionally, a continuous infusion of piritramid 150 $\mu \mathrm{g} \cdot \mathrm{kg}^{-1} \cdot \mathrm{h}^{-1}$ and alcuronium $75 \mu \mathrm{g} \cdot \mathrm{kg}^{-1} \cdot \mathrm{h}^{-1}$ was installed after termination of surgical preparation. For replacement of fluid losses, Ringer's solution 5 $\mathrm{ml} \cdot \mathrm{kg}^{-1} \cdot \mathrm{h}^{-1}$ was administered throughout the experiment. A warming pad was used to keep core body temperature between 35.9 and $36.8^{\circ} \mathrm{C}$. The dogs were intubated and mechanically ventilated at a rate of 12 cycles $\cdot \mathrm{min}^{-1}$ at a tidal volume $\left(\mathrm{V}_{\mathrm{T}}\right)$ of $15-18 \mathrm{ml} \cdot \mathrm{kg}^{-1}$ using $100 \% \mathrm{O}_{2}$ (Servo Siemens C, Siemens-Elema, Solna, Sweden). $\mathrm{V}_{\mathrm{T}}$ was adjusted to obtain an initial arterial $\mathrm{PCO}_{2}$ between 4.7 and $5.3 \mathrm{kPa}(35-40 \mathrm{~mm} \mathrm{Hg})$.

\section{SURGICAL PREPARATION}

Fluid filled catheters (PP270, Portex, Hythe, UK) were positioned in the descending aorta and superior vena cava via the left femoral artery and the right external jugular vein respectively. A thermistor tipped, flow directed catheter (Swan-Ganz, 7F, Edwards, Anasco, Puerto Rico) was inserted into the pulmonary artery via the right external jugular vein. Left ventricular pressure was measured by a tip manometer (PC 350, Millar Instruments, Houston, TX, USA) introduced via the right common carotid artery. After a right thoracotomy (5th intercostal space) and pericardiotomy, a second tip manometer was inserted into the right ventricle via an atrial stab incision. Thereafter, two pairs of miniaturised (external diameter $1.5-2 \mathrm{~mm}$ ) piezoceramic ultrasonic transducers ${ }^{13}$ were implanted in the longitudinal axis of the inflow tract and the outflow tract of the right ventricular free wall (fig 1). Each crystal was inserted via a stab incision and secured with an epicardial purse string suture (5-0 prolene ${ }^{\circledR}$, Ethicon, Norderstedt, FRG). At the end of surgical preparation, the pericardium was sutured without constraint to the myocardium, after which the chest was closed air right, the lungs were reinflated and the remaining air removed by a chest drain.

\section{EVALUATION OF METHODS}

The implanted pressure transducers and their amplifying units were tested for stable zero and linearity of gain: drift was less than $0.13 \mathrm{kPa}(1 \mathrm{~mm}$ $\mathrm{Hg}$ ) at temperatures ranging from $34^{\circ}-37^{\circ} \mathrm{C}$ and gain

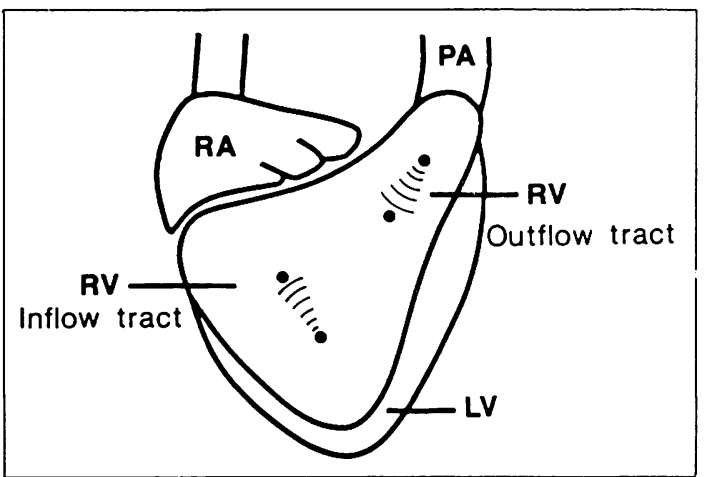

Figure 1 Ultrasonic crystals have been implanted in the longitudinal axes of the inflow and outflow tract of the right ventricular $(R V)$ free wall. $R A=$ right atrium; $P A=$ pulmonary artery; $L V=$ left ventricle.

was found linear up to $26.6 \mathrm{kPa}(200 \mathrm{~mm} \mathrm{Hg})$. Prior to each experiment, the catheters (in a $36^{\circ} \mathrm{C}$ water bath) and amplifiers were prewarmed for at least $12 \mathrm{~h}$ and were calibrated immediately before use. After the end of the experiment, a second calibration was performed. The measured drift of electrical zero was less than 0.05 $\mathrm{kPa}(0.3 \mathrm{~mm} \mathrm{Hg})$ per hour. To prevent this drift from producing a significant error over a period of hours of low pressure measurement, a computerised drift correction was performed in every experiment (assuming linearity of drift between the first and last measurement).

\section{MEASUREMENTS}

All measurements were performed with the dogs in the left lateral position. Mean arterial and mean pulmonary artery pressure were recorded using Statham P23D6 transducers (Gould-Statham, Oxnard, CA, USA) referred to the right atrium and zeroed to atmospheric pressure. During data acquisition, phasic ventricular pressures, phasic contraction of myocardial segments and the ECG were sampled every $4 \mathrm{~ms}$, digitised in real time (A/D Converter C1000, Cosima, Salem, OR, USA) and stored for subsequent evaluation using a PDP 11/03 computer system (DEC, Maynard, MA, USA). Data were analysed with interactive software developed in our laboratory. All signals were evaluated at end expiration using an average of three consecutive beats. We assessed mean, systolic and end diastolic pressures in the right and left ventricles. The rate of right ventricular pressure rise $(\mathrm{dRVP} / \mathrm{dt})$ was derived from the phasic right ventricular pressure curve by differentiation (Gould-Brush differentiator 13-4214-01, Cleveland, $\mathrm{OH}, \mathrm{USA})$. Cardiac output was obtained in triplicate by thermodilution technique (SP1435, GouldStatham, Oxnard, CA, USA).

Arterial and mixed venous blood were analysed for $\mathrm{PO}_{2}, \mathrm{PCO}_{2}$, base excess and $\mathrm{pH}$ (ABL 3, Radiometer, Copenhagen, Denmark). $\mathrm{CO}_{2}$ production per minute 
$\left(\dot{\mathrm{V}} \mathrm{CO}_{2}\right)$ was measured by a $\mathrm{CO}_{2}$ analyser 930 (Siemens-Elema, Solna, Sweden). Effective pulmonary compliance and expiratory resistance were assessed by a Lung Mechanics Calculator 940 (Siemens-Elema, Solna, Sweden) connected to the ventilator.

\section{CALCULATIONS}

The following haemodynamic and respiratory variables were calculated: cardiac index $(\mathrm{CI})=$ $10 \cdot \mathrm{CO} \cdot \mathrm{BW}^{-0.75}$ (according to ${ }^{14}$ ); stroke index $(\mathrm{SI})=$ $\mathrm{CI} \cdot 1000 \cdot \mathrm{HR}^{-1}$; and pulmonary vascular resistance $(\mathrm{PVR})=\left(\mathrm{PAP}_{\text {mean }}-\mathrm{LVEDP}\right) \cdot 79.9 \cdot \mathrm{CO}^{-1}$; where $\mathrm{CO}=$ cardiac output, $\mathrm{BW}=$ body weight, $\mathrm{HR}=$ heart rate, $\mathrm{PAP}_{\text {mean }}=$ mean pulmonary artery pressure, and LVEDP $=$ left ventricular end diastolic pressure.

Intrapulmonary shunt $\left(\dot{Q}_{S} / \dot{Q}_{t}\right)$ was calculated as

$$
\dot{\mathrm{Q}}_{\mathrm{s}} / \dot{\mathrm{Q}}_{\mathrm{t}}=\left(\mathrm{CcO}_{2}-\mathrm{CaO}_{2}\right) /\left(\mathrm{CcO}_{2}-\mathrm{CvO}_{2}\right) \text {, }
$$

where $\mathrm{CcO}_{2}=\mathrm{Hb} \cdot 1.39+0.0031 \cdot\left(\mathrm{P}_{\mathrm{B}}-47-\mathrm{PaCO}_{2}\right)$, $\mathrm{CaO}_{2}=\left(\mathrm{Hb} \cdot 1.39 \cdot \mathrm{SaO}_{2}\right) / 100+0.0031 \cdot \mathrm{PaO}_{2}$, and $\mathrm{CvO}_{2}$ $=\left(\mathrm{Hb} \cdot 1.39 \cdot \mathrm{SvO}_{2}\right) / 100+0.0031 \cdot \mathrm{PvO}_{2} \cdot \mathrm{CcO}_{2}, \mathrm{CaO}_{2}$ and $\mathrm{CvO}_{2}$ are $\mathrm{O}_{2}$ contents in ideal $(100 \%$ saturated $)$ pulmonary capillary, systemic arterial and mixed venous blood, respectively. $\mathrm{Hb}$ is haemoglobin, $\mathrm{P}_{\mathrm{B}}$ is barometric pressure, $\mathrm{PaO}_{2}$ and $\mathrm{PaCO}_{2}\left(\mathrm{PvO}_{2}\right.$ and $\left.\mathrm{PvCO}_{2}\right)$ are arterial (mixed venous) $\mathrm{PO}_{2}$ and $\mathrm{PCO}_{2}$, respectively. $\mathrm{SaO}_{2}$ and $\mathrm{SvO}_{2}$ are percent arterial and mixed venous $\mathrm{O}_{2}$ saturation and were derived from the blood gas tensions according to the nomogram of Rossing and Cain. ${ }^{15}$ The ratio of physiological dead space to tidal volume $\left(V_{D} / V_{T}\right)$ was determined by the Enghoff modification of the Bohr equation as $\mathrm{V}_{\mathrm{D}} / \mathrm{V}_{\mathrm{T}}=$ $\left(\mathrm{PaCO}_{2}-\mathrm{PeCO}_{2}\right) \cdot 100 / \mathrm{PaCO}_{2}$, where $\mathrm{PeCO}_{2}$ (partial pressure of mean expiratory $\mathrm{CO}_{2}$ ) was calculated as $\mathrm{PeCO}_{2}=\dot{\mathrm{V} C O} \cdot \cdot\left(\mathrm{P}_{\mathrm{B}}-47\right) /\left(\mathrm{V}_{\mathrm{T}} \cdot \mathrm{RR}\right), \mathrm{VCO}_{2}$ being the $\mathrm{CO}_{2}$ minute production. The alveolar gas equation was used to calculate alveolar-arterial $\mathrm{O}_{2}$ difference $\left(\mathrm{AaDo}_{2}\right)$.

\section{SONOMICROMETRY}

Sonomicrometry provides an accurate description of the distance between two ultrasonic transducers. ${ }^{16}$ Myocardial segment lengths were measured at end diastole $\left(\mathrm{L}_{\mathrm{dia}}\right)$ and end systole $\left(\mathrm{L}_{\text {sys }}\right)$. End diastole was defined as the beginning of the upstroke of $d R V P / d t$, end systole as maximum negative $\mathrm{dRVP} / \mathrm{dt}$. Although true end systole is difficult to assess in the right ventricle, maximal negative $\mathrm{dRVP} / \mathrm{dt}$ has been shown to reflect accurately the end of right ventricular ejection at normal and increased afterload. ${ }^{17}$ Maximum and minimum segment length $\left(\mathrm{L}_{\max }, \mathrm{L}_{\min }\right)$ were also determined. All length values were normalised by assuming segment length at end diastole in control to be $10 \mathrm{~mm} .{ }^{18}$ To quantify the pattern of local segment motion, the percentage of maximal $\left(\mathrm{S}_{\max }\right)$, systolic $\left(\mathrm{S}_{\mathrm{sys}}\right)$ and postsystolic fibre shortening $\left(S_{\text {psys }}\right)$ as well as protosystolic elongation ("bulging") were defined as follows:

$$
\begin{aligned}
\mathrm{S}_{\text {sys }} & =\left(\mathrm{L}_{\mathrm{dia}}-\mathrm{L}_{\mathrm{sys}}\right) \cdot 100 / \mathrm{L}_{\mathrm{dia}} \\
\mathrm{S}_{\max } & =\left(\mathrm{L}_{\max }-\mathrm{L}_{\min }\right) \cdot 100 / \mathrm{L}_{\max } \\
\mathrm{S}_{\mathrm{psys}} & =\left(\mathrm{L}_{\mathrm{sys}}-\mathrm{L}_{\min }\right) \cdot 100 / \mathrm{L}_{\text {sys }} \\
\text { "bulging" } & =\left(\mathrm{L}_{\text {max }}-\mathrm{L}_{\text {dia }}\right) \cdot 100 / \mathrm{L}_{\text {dia }}
\end{aligned}
$$

To visualise the dynamics of right ventricular free wall contraction, pressure-length loops were constructed by plotting phasic changes of segment length against phasic changes of right ventricular pressure during one cardiac cycle by computer. Sonomicrometric data were obtained from 13 animals in the right ventricular inflow tract and from 12 animals in the right ventricular outflow tract.

\section{EXPERIMENTAL PROTOCOL}

After surgical preparation, the animals were isovolaemically haemodiluted with dextran 60 (Makrodex ${ }^{\circledR} 6 \%$, Schiwa, Glandorf, FRG) to a packed cell volume of $30 \%$. Packed cell volume was intentionally reduced to achieve identical baseline values of packed cell volume and haemoglobin concentration in all animals. The removed blood was used for replacement of blood samples taken for laboratory analyses during the experiment.

Following a stabilisation period of $30 \mathrm{~min}$, control measurements were performed. Thereafter, the lungs were embolised by injection of a single dose of oleic acid $\left(0.01 \mathrm{ml} \cdot \mathrm{kg}^{-1}\right)$ into the right atrium, followed by repetitive doses $\left(0.5-1\right.$ g every $3-5 \mathrm{~min}$; total $\left.0.5 \mathrm{~g} \cdot \mathrm{kg}^{-1}\right)$ of non-siliconised glass beads (diameter $100 \mu \mathrm{m}$ ) suspended and thoroughly mixed in 1-2 $\mathrm{ml}$ of dextran 60. Embolisation was interrupted when mean pulmonary artery pressure had increased by $10-15 \mathrm{~mm}$ $\mathrm{Hg} ; 10 \mathrm{~min}$ later a second set of measurements was performed $\left(\mathrm{APME}_{1}\right)$. Thereafter, embolisation continued and was terminated when mean pulmonary artery pressure had reached a peak level of $\approx 40 \mathrm{~mm}$ $\mathrm{Hg} .{ }^{19} \mathrm{~A}$ third set of measurements was obtained $10 \mathrm{~min}$ after the end of acute pulmonary microembolisation $\left(\mathrm{APME} \mathrm{E}_{2}\right)$.

\section{STATISTICAL ANALYSIS}

Data are presented as means (SD) when normally distributed (haemodynamic variables, lung function); otherwise (sonomicrometry) the median and $Q_{1} / Q_{3}$ quartiles are given. Statistical evaluation was performed using SAS (5th edition, SAS Institute, Cary, MA, USA). A repeated measures analysis of variance (rANOVA) was used to test for the existence of an overall effect of the intervention (acute pulmonary microembolisation $=\mathrm{APME}$ ) on a variable. In case of a significant $F$ value $(p<0.05)$ in the rANOVA, the following time points were compared by a paired $t$ test (haemodynamic variables, lung function) or by Wilcoxon's signed rank test (sonomicrometry), respectively: $\mathrm{APME}_{1} v$ control, $\mathrm{APME}_{2} v \mathrm{APME}_{1}$, $\mathrm{APME}_{2} v$ control. Differences were considered significant at $\mathrm{p}<0.05$. 


\section{Results}

HAEMODYNAMIC VARIABLES

The changes in haemodynamic variables induced by acute pulmonary microembolisation are shown in table I. According to the protocol, embolisation was interrupted when pulmonary artery pressure had increased by $10-15 \mathrm{~mm} \mathrm{Hg}\left(\mathrm{APME}_{1}\right)$. At this time, there was a 3.5-fold rise in pulmonary vascular resistance and a significant $30 \%$ increase in mean and systolic right ventricular pressure, while end diastolic right ventricular pressure remained unchanged. In contrast, left ventricular end diastolic pressure had decreased, accompanied by a slight fall in mean left ventricular and aortic pressures. Despite a reduced stroke index, cardiac index was maintained as a result of a rise in heart rate. At peak pulmonary artery pressure $\left(A P M E_{2}\right)$, right ventricular end diastolic pressure had slightly but significantly increased as compared to control and APME 1 . Pulmonary vascular resistance and right ventricular systolic and mean pressure had reached a maximum, while end diastolic and mean left ventricular pressure as well as mean aortic pressure continued to decrease. Despite the lower stroke index, no depression of cardiac index was observed due to further increase of heart rate.

\section{LUNG FUNCTION}

Changes in lung function and blood gases induced by acute pulmonary microembolisation are shown in table II. Lung mechanics (compliance, resistance) and gas exchange $\left(\mathrm{PaO}_{2}\right.$, alveolar-arterial $\mathrm{O}_{2}$ difference, shunt, dead space) had deteriorated at $\mathrm{APME}_{1}$ and even more at $\mathrm{APME}_{2}$. Embolisation resulted in hypercapnia and respiratory acidosis at $\mathrm{APME}_{2}$.

\section{SONOMICROMETRY}

Right ventricular segment lengths - Table III summarises the data of local segment lengths before

Table I Changes in haemodynamic variables after pulmonary microembolism. Results are means (SD).

\begin{tabular}{|c|c|c|c|}
\hline & \multirow[t]{2}{*}{ Control } & \multicolumn{2}{|c|}{ Pulmonary microembolism } \\
\hline & & $\mathrm{APME}_{1}$ & $\mathrm{APME}_{2}$ \\
\hline $\begin{array}{l}\left.\mathrm{HR} \text { (beats } \min ^{-1}\right) \\
\mathrm{CI}\left(\text { litre } \cdot \mathrm{min}^{-1} \cdot \mathrm{BW}^{-0.75}\right) \\
\text { SI }\left(\mathrm{ml} \cdot \mathrm{BW}^{-0.75}\right)\end{array}$ & $\begin{array}{l}104(26) \\
4.0(4.0) \\
40(9)\end{array}$ & $\begin{array}{l}117(22)^{\star \star \star} \\
3.8(0.4) \\
34(6)^{\star \star \star}\end{array}$ & $\begin{array}{l}140(23)^{\star \star \star}+1 \dagger \\
4.1(0.6) \\
30(6)^{\star}+\dagger \dagger\end{array}$ \\
\hline $\begin{array}{l}\text { RV pulmonary haemody } \\
\text { PAP } \\
\text { PVRean }\left(\mathrm{mm} \mathrm{Hg} \mathrm{Hg} \cdot \mathrm{litr}^{-1} \cdot \mathrm{min}\right) \\
\text { RVP }_{\text {mean }}(\mathrm{mm} \mathrm{Hg}) \\
\text { RVP }_{\text {sys }}(\mathrm{mm} \mathrm{Hg}) \\
\text { RVEDP }(\mathrm{mm} \mathrm{Hg})\end{array}$ & $\begin{array}{l}11(2) \\
175(97) \\
9(3) \\
24(4) \\
4.0(3.3)\end{array}$ & $\begin{array}{l}22(2) \\
617(145)^{\star \star \star \star} \\
13(3)^{\star \star \star} \\
32(6)^{\star \star \star} \\
4.5(2.5)\end{array}$ & $\begin{array}{l}39(4) \\
1221(445)^{\star \star \star \star}+\dagger \dagger \\
23(5)^{\star \star \star+十 \dagger} \\
48(9)^{\star \star \star \star \dagger \dagger \dagger} \\
5.7(3.2)^{\star \star \dagger}\end{array}$ \\
\hline $\begin{array}{l}\text { LV systemic haemodyna } \\
\text { MAP } \text { mean }(\mathrm{mm} \mathrm{Hg}) \\
\text { LVP }_{\text {mean }}(\mathrm{mm} \mathrm{Hg}) \\
\text { LVEDP }(\mathrm{mm} \mathrm{Hg})\end{array}$ & $\begin{array}{l}106(15) \\
43(7) \\
5.5(2.3)\end{array}$ & $\begin{array}{l}96(17)^{\star \star \star \star} \\
40(6)^{\star \star \star} \\
4.0(2.0)^{\star \star \star}\end{array}$ & $\begin{array}{l}85(17) \star \star t+\dagger \\
39(8)+t \\
3.3(2.0)+\dagger\end{array}$ \\
\hline
\end{tabular}

$\mathrm{APME}_{1}=$ measurements made after microembolisation caused mean pulmonary artery pressure $\left(\mathrm{PAP}_{\text {mean }}\right)$ to increase by $10-15 \mathrm{~mm} \mathrm{Hg}$; $A P M E_{2}=$ measurements made when $P A P$ mean reached $\approx 40 \mathrm{~mm} \mathrm{Hg} ; \mathrm{HR}=$ heart rate; $\mathrm{SI}=$ stroke index; $\mathrm{CI}=$ cardiac index; $\mathrm{PVR}=$ pulmonary vascular resistance; $R P_{\text {mean }}=$ mean right ventricular $(R V)$ pressure; $R V P_{\text {sys }}=$ systolic $R V$ pressure; $R V E D P=e n d$ diastolic $R V$ pressure; $\mathrm{MAP}_{\text {mean }}=$ mean arterial pressure; $\mathrm{LVP}_{\text {mean }}=$ mean left ventricular $(\mathrm{LV})$ pressure; $L V E D P=$ end diastolic $L V$ pressure.

${ }^{\star} \mathrm{p}<0.05,{ }^{\star} \mathrm{p}<0.01,{ }^{\star \star \star} \mathrm{p}<0.001$ (APME 1 control, $\mathrm{APME}_{2} v \mathrm{APME}_{1}$ ); $\mathrm{p}<<0.05, \dagger+\mathrm{p}<0.01, \dagger \dagger \dagger \mathrm{p}<0.001$ (APME 2 control). No statistical test was performed on PAP mean because this variable was intentionally changed by microembolisation.

Table II Changes in lung function after pulmonary microembolism. Results are means (SD).

\begin{tabular}{|c|c|c|c|}
\hline & \multirow[t]{2}{*}{ Control } & \multicolumn{2}{|c|}{ Pulmonary microembolism } \\
\hline & & $\mathrm{APME}_{1}$ & $\mathrm{APME}_{2}$ \\
\hline $\begin{array}{l}\text { Lung mechanics } \\
\mathrm{C}_{\text {eff }}\left(\mathrm{ml}^{1} \cdot \mathrm{kPa}^{-1}\right) \\
\mathrm{R}_{\exp }\left(\mathrm{kPa}^{\prime} \cdot \mathrm{s}^{\prime} \cdot \mathrm{litr}^{-1}\right)\end{array}$ & $\begin{array}{l}386(65) \\
1.07(0.09)\end{array}$ & $\begin{array}{l}355(79)^{\star} \\
1.19(0.19)^{\star}\end{array}$ & $\begin{array}{l}315(59)^{\star \star \star}+\dagger \dagger \\
1.30(0.17)^{\star \star \star+十 \dagger}\end{array}$ \\
\hline $\begin{array}{c}\text { Gas exchange } \\
\mathrm{PaO}_{2}(\mathrm{kPa}) \\
\mathrm{PaCO}_{2}(\mathrm{kPa}) \\
\mathrm{AaDO}_{2}(\mathrm{kPa}) \\
\mathrm{Q}_{\mathrm{s}} / \mathrm{Q}_{1}(\%) \\
\mathrm{V}_{\mathrm{D}} / \mathrm{V}_{\mathrm{T}}(\%)\end{array}$ & $\begin{array}{l}74.9(5.9) \\
5.1(0.3) \\
14.8(5.6) \\
9(4) \\
51(4)\end{array}$ & $\begin{array}{l}70.4(7.6)^{\star \star \star} \\
5.4(0.4)^{\star \star \star} \\
19.6(7.3)^{\star \star \star} \\
12(5)^{\star \star} \\
54(5)^{\star \star}\end{array}$ & $\begin{array}{l}49.1(18.5)^{\star \star \star}+\dagger+ \\
6.5(0.8)^{\star \star \star}+\dagger \dagger \\
42.1(18.5)^{\star \star \star}+\dagger \dagger \\
22(10)^{\star \star}+\dagger \dagger \\
66(8)^{\star \star \star t+\dagger}\end{array}$ \\
\hline $\begin{array}{l}\text { Acid base status } \\
\mathrm{pH} \\
\mathrm{BE}\left(\mathrm{mmol} \cdot \text { litre }^{-1}\right)\end{array}$ & $\begin{array}{l}7.32(0.02) \\
-5.8(1.3)\end{array}$ & $\begin{array}{l}7.30(0.02)^{\star \star} \\
-5.9(0.9)\end{array}$ & $\begin{array}{l}7.23(0.04)^{\star \star \star} \dagger \dagger \dagger \\
-6.9(1.2)^{\star \star}+\dagger\end{array}$ \\
\hline
\end{tabular}

$\mathrm{C}_{\text {eff }}=$ effective pulmonary compliance; $\mathrm{R}_{\text {exp }}=$ expiratory resistance; $\mathrm{PaO}_{2}=$ partial pressure of arterial oxygen; $\mathrm{PaCO}{ }_{2}=$ partial pressure of arterial $\mathrm{CO}_{2} ; \mathrm{AaDO}_{2}=$ alveolar-arterial oxygen difference; $\mathrm{Q}_{\mathrm{s}} / \mathrm{Q}_{\mathrm{t}}=$ intrapulmonary shunt; $\mathrm{V}_{\mathrm{D}} / \mathrm{V}_{\mathrm{T}}=$ physiological dead space, $\mathrm{BE}=$ base excess. See table $\mathrm{I}$ for other abbreviations.

${ }^{\star} \mathrm{p}<0.05,{ }^{\star \star} \mathrm{p}<0.01,{ }^{\star \star \star} \mathrm{p}<0.001\left(\mathrm{APME}_{1} v\right.$ control, $\left.\mathrm{APME}_{2} v \mathrm{APME}_{1}\right) ; \mathrm{tp}<0.05$, †tp $<0.01$, †† 
Table III Changes in right ventricular segment lengths after pulmonary microembolism. Results are median $\left(Q_{1} / Q_{3}\right.$ quartiles $)$.

\begin{tabular}{|c|c|c|c|}
\hline & \multirow[t]{2}{*}{ Control } & \multicolumn{2}{|c|}{ Pulmonary microembolism } \\
\hline & & $\mathrm{APME}_{1}$ & $\mathrm{APME}_{2}$ \\
\hline \multicolumn{4}{|c|}{ Inflow tract $(n=13)$} \\
\hline $\mathrm{L}_{\mathrm{dla}}(\mathrm{mm})$ & 10.0 & \multirow{4}{*}{$\begin{array}{l}10.1^{\star} \\
(10.0-10.2) \\
10.3^{\star} \\
\left(10.2^{-1}-10.5\right) \\
9.7^{\star \star} \\
(9.2-9.9) \\
9.6^{\star \star} \\
(9.1-9.8)\end{array}$} & \multirow{4}{*}{$\begin{array}{l}10.3^{\star \star} \dagger \dagger \\
(10.1-10.5) \\
10.5^{\star \star}+\dagger \\
(10.4-10.6) \\
9.8^{\star \star \dagger \dagger} \\
(9.4-10.2) \\
9.6+\dagger \\
(9.4-9.9)\end{array}$} \\
\hline $\mathrm{L}_{\max }(\mathrm{mm})$ & $\begin{array}{l}10.2 \\
(10.1-10.3)\end{array}$ & & \\
\hline $\mathrm{L}_{w}(\mathrm{~mm})$ & $\begin{array}{l}9.4 \\
(9.0-9.8)\end{array}$ & & \\
\hline $\mathrm{L}_{\min }(\mathrm{mm})$ & $\begin{array}{l}9.2 \\
(9.0-9.6)\end{array}$ & & \\
\hline \multicolumn{4}{|c|}{ Outflow tract $(n=12)$} \\
\hline $\mathrm{L}_{\mathrm{dia}}(\mathrm{mm})$ & 10.0 & \multirow{4}{*}{$\begin{array}{l}9.7^{\star \star} \\
(9.6-9.9) \\
9.8 \\
(9.7-10.3) \\
9.0^{\star \star} \\
(8.5-9.8) \\
8.7 \\
(8.3-9.1)\end{array}$} & \multirow{4}{*}{$\begin{array}{l}9.6 \dagger \\
(9.5-9.9) \\
9.9 \\
(9.5-10.5) \\
9.2+\dagger \\
(8.8-10.1) \\
8.9 \\
(8.5-9.3)\end{array}$} \\
\hline $\mathrm{L}_{\max }(\mathrm{mm})$ & $\begin{array}{l}10.1 \\
(10.0-10.2)\end{array}$ & & \\
\hline $\mathrm{L}_{\mathrm{sw}}(\mathrm{mm})$ & $\begin{array}{l}8.8 \\
(8.5-9.4)\end{array}$ & & \\
\hline $\mathrm{L}_{\min }(\mathrm{mm})$ & $\begin{array}{l}8.5 \\
(8.2-9.1)\end{array}$ & & \\
\hline
\end{tabular}

$\mathrm{L}_{\mathrm{dia}}=$ end diastolic segment length $(\mathrm{SL}), \mathrm{L}_{\max }=$ maximal $\mathrm{SL}$, $\mathrm{L}_{\mathrm{s} w \mathrm{l}}=$ end systolic $\mathrm{SL}, \mathrm{L}_{\min }=$ minimal $\mathrm{SL}$. For other abbreviations see tabile I.

${ }^{\star} \mathrm{p}<0.05,{ }^{\star \star} \mathrm{p}<0.01\left(\mathrm{APME}_{1} v\right.$ control, $\left.\mathrm{APME}_{2} v \mathrm{APME}_{1}\right) ; \mathrm{p}<0.05$ $\dagger+\mathrm{p}<0.01$ ( $\mathrm{APME}_{2} v$ control).

and after acute pulmonary microembolisation. In the right ventricular inflow tract end diastolic length $\left(\mathrm{L}_{\mathrm{dia}}\right)$ was increased at $A P M E_{1}$ and $A P M E_{2}$, while in the outflow tract it decreased significantly. This finding is shown most clearly in fig 2 , where control values of end diastolic length are depicted with the values at $A P M E_{2}$ for each experiment. In the right ventricular inflow tract, end diastolic length did not change in two experiments, but was increased in 11 . In contrast, end diastolic length in the outflow tract was considerably decreased in 10 of 12 animals.

When maximal segment length $\left(\mathrm{L}_{\max }\right)$ was analysed in place of end diastolic length, similar results were obtained (table III, fig 2). Maximal segment length in the right ventricular inflow tract was increased at $\mathrm{APME}_{2}$ in all experiments, whereas in the outflow tract it declined in nine of 12 animals.

While end diastolic and maximal segment lengths were affected differently by pulmonary microembolism in the right ventricular inflow and outflow tracts, changes in systolic and minimal segment length were found to be similar, ie, systolic and minimal length significantly and equivalently increased subsequent to embolisation in both regions of the right ventricular free wall (table III).

Right ventricular segment shortening - Table IV (pooled data) and fig 3 (single experiments) show that systolic and maximal shortening were not significantly altered by acute pulmonary microembolisation in the right

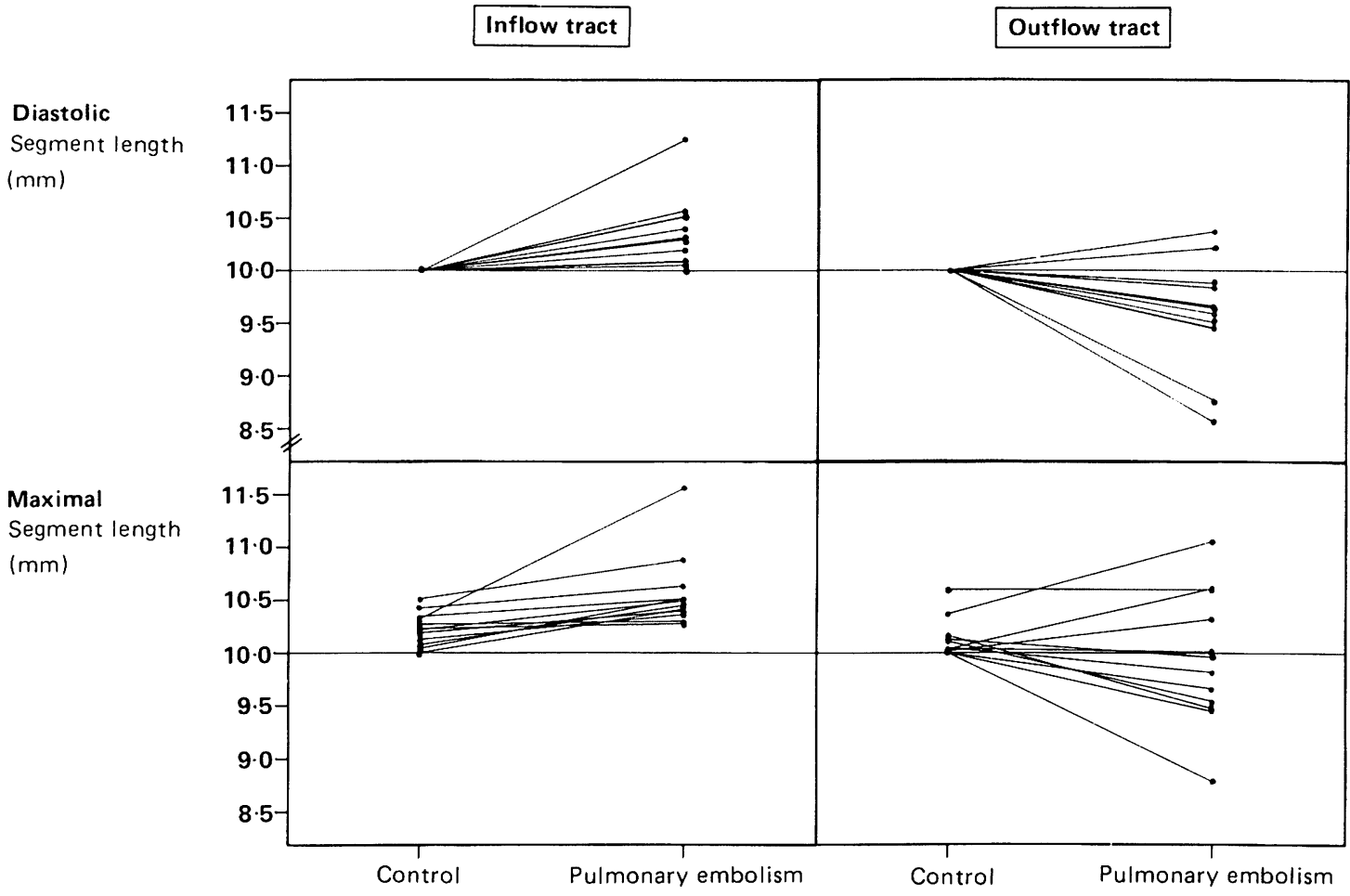

Figure 2 For each experiment, end diastolic and maximal myocardial segment length in the right ventricular inflow and outflow tracts have been compared before (control) and after acute pulmonary microembolism ( $=A P M E_{2}$, see table I for explanation). 
Table IV Changes in right ventricular segment shortening after pulmonary microembolism. Results are median $\left(Q_{l} / Q_{3}\right.$ quartiles).

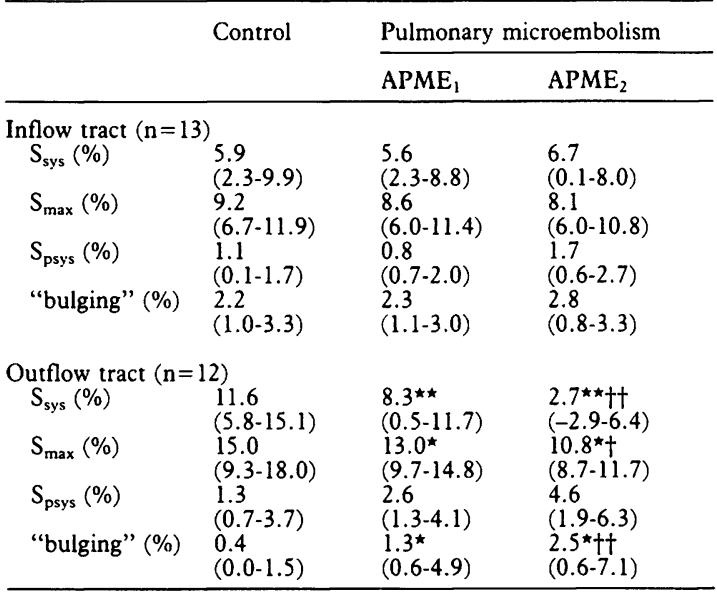

$\mathrm{S}_{\mathrm{sys}}=$ systolic shortening of the myocardial segment; $\mathrm{S}_{\max }=$ maximal segment shortening; $S_{\text {psys }}=$ postsystolic segment shortening; "bulging"= protosystolic segment elongation. For other abbreviations see table I.

${ }^{\star} \mathrm{p}<0.05,{ }^{\star \star} \mathrm{p}<0.01\left(\mathrm{APME}_{1} v\right.$ control, $\left.\mathrm{APME} \mathrm{E}_{2} v \mathrm{APME} \mathrm{E}_{1}\right) ; \mathrm{tp}<0.05$, ††p $<0.01$ ( $\mathrm{APME}_{2} v$ control).

ventricular inflow tract. The unchanged amplitude of contraction results from an equal rise of systolic (minimal) and diastolic (maximal) segment length (see above). In contrast, a significant fall in systolic and maximal shortening subsequent to microembolisation was observed in the right ventricular outflow tract, originating from lowered diastolic (maximal) segment length in the presence of increased systolic (minimal) length. As seen in fig 3, microembolisation reduced the amplitude of local outflow tract contraction in all experiments.

In both regions of the right ventricular free wall, paradoxical systolic elongation $\hat{=}$ negative systolic shortening) was absent at control, but present in three (inflow tract) and four (outflow tract) animals as a result of the microembolisation (fig 3 ). There was no difference in the extent of postsystolic shortening in the two regions before and after microembolisation. However "bulging" was found at any level of microembolisation in the right ventricular outflow tract, but not in the inflow tract. It should be noted that the degree of "bulging" was different in the two regions at control (table IV) and that microembolisation eliminated this difference by increasing "bulging" in outflow tract without affecting the inflow tract.

Right ventricular pressure-length loops - Pressurelength loops of right ventricular inflow and outflow tracts from four experiments are shown in fig 4 . While

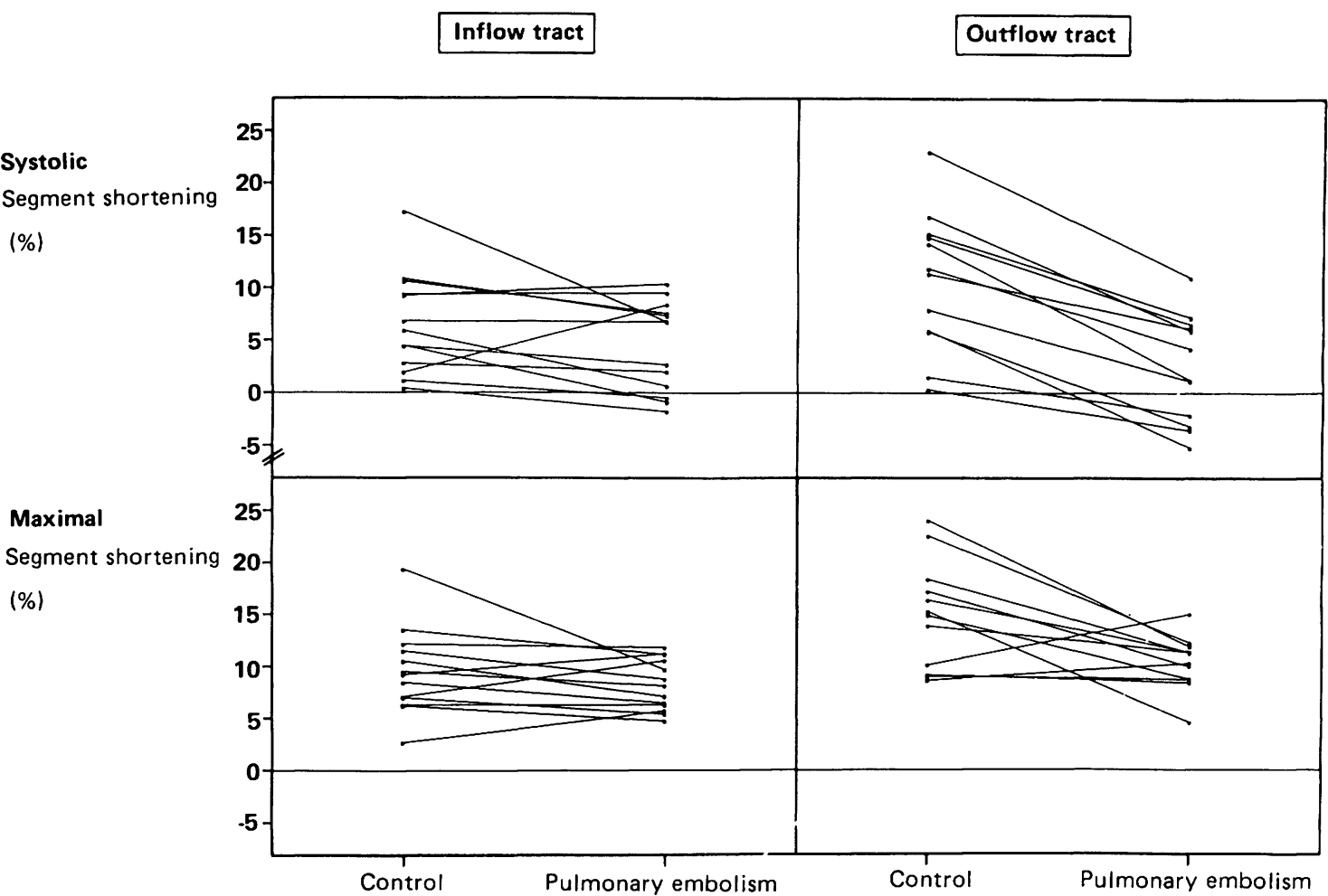

Figure 3 For each experiment, systolic and maximal myocardial segment shortening in the right ventricular inflow and outflow tracts

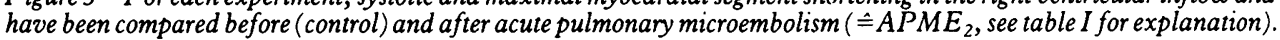



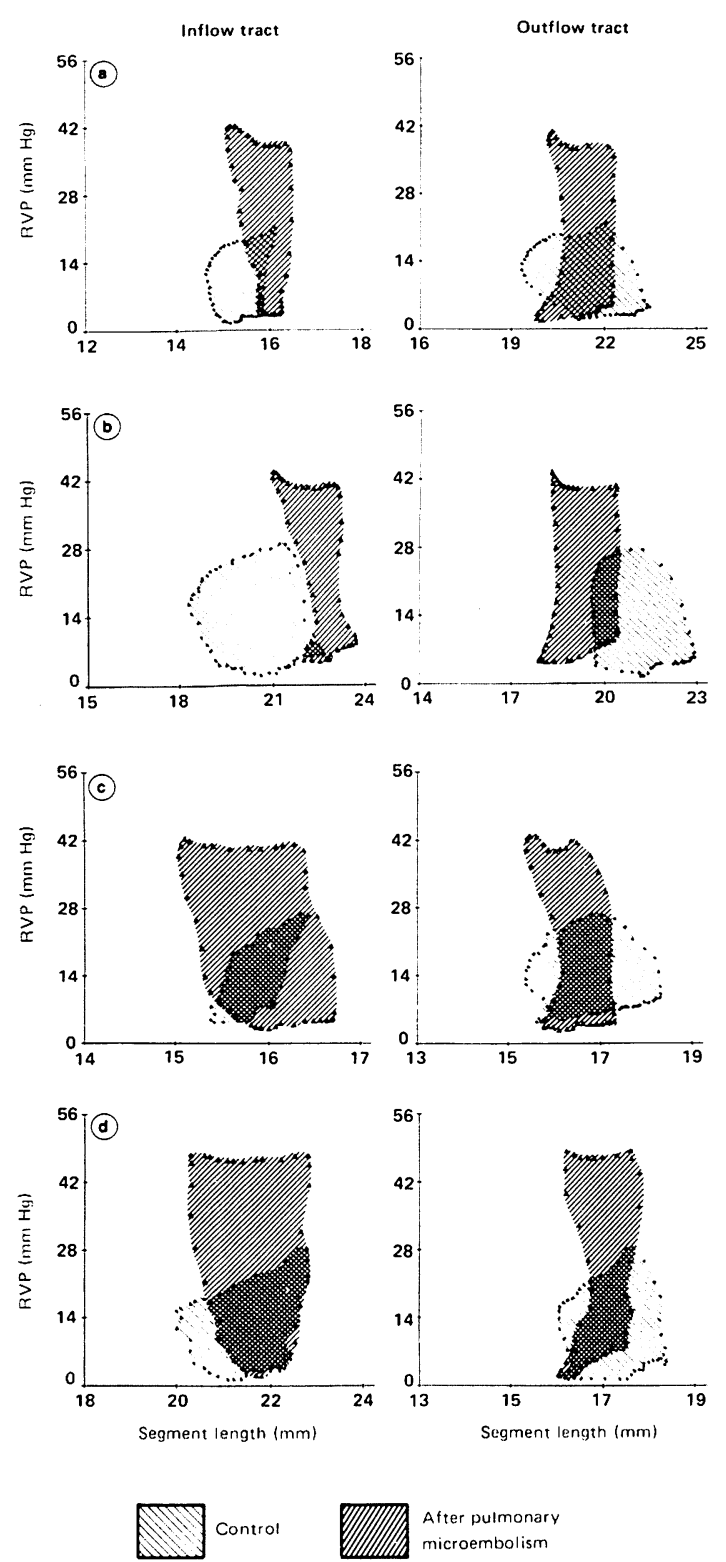

Figure 4 Pressure-length loops from segments of the right ventricular inflow tract (left graphs) and outflow tract (right graphs) have been constructed for four experiments $(a-d)$ before and after acute pulmonary microembolism ( $\triangleq A P M E_{2}$, see table I for explanation). Embolisation resulted in a shift to the right (or no shift in d) of loops from the inflow tract. In contrast, loops from the outflow tract were shifted to the left (for further details see

Results).

at control, the loops were found to be triangular or oval in shape, they became rectangular after pulmonary embolism $\left(\mathrm{APME}_{2}\right)$. No major differences in these qualitative changes of the dynamic contraction pattern were observed between the inflow and outflow tracts. However, the segment length at which the steep rise of right ventricular pressure occurred $\left(\hat{=} \mathrm{L}_{\mathrm{dia}}\right.$ ), was influenced differently by microembolisation: within the same experiment, end diastolic segment length was increased or remained unchanged in the right ventricular inflow tract, but declined in the outflow tract (fig 4). Consequently, the loops were shifted to the right in the inflow tract or to the left in the outflow tract. Segment shortening was decreased (fig 4b), unaffected (fig 4a,d) or increased (fig 4c) in the inflow tract, while shortening in the outflow tract worsened in all experiments. Figures $4 \mathrm{~b}$ and $4 \mathrm{~d}$ suggest that a dissociation of end diastolic pressure and end diastolic segment length may occur in the right ventricular outflow tract subsequent to acute microembolisation: while the end diastolic pressure increased, end diastolic length considerably decreased in these experiments.

\section{Discussion}

The inflow tract and outflow tract of the right ventricle are known to differ with respect to origin, morphology, innervation and function. ${ }^{16} 20-24$ For these reasons, changes of local myocardial fibre lengths and local contraction pattern have been assessed after pulmonary microembolisation separately in bath regions of the right ventricular free wall. It was our aim to determine whether the myocardial fibres of the right ventricular free wall respond uniformly to an acute increase in right ventricular afterload. Studies addressing this topic in the past ${ }^{162526}$ have been performed in pericardectomised, open chest dogs ${ }^{16} 25$ and most often pulmonary hypertension was induced by mechanical narrowing of the pulmonary artery. ${ }^{16} 26$ These experimental settings, however, do not adequately reflect the clinical situation ${ }^{27}{ }^{28}$ of patients presenting with a closed chest/pericardium and pulmonary hypertension due to microvascular injury rather than to pulmonary constriction. ${ }^{29} 30$

In the present study, pericardium and chest were closed after surgery and right ventricular afterload was increased by acute microembolisation of the lungs resulting in profound changes in pulmonary function. The decrease of $\mathrm{PaO}_{2}$ and effective pulmonary compliance and the increase of $\mathrm{AaDo}_{2}, \dot{\mathrm{Q}}_{\mathrm{s}} / \dot{\mathrm{Q}}_{1}, \mathrm{PaCO}_{2}$, and $\mathrm{V}_{\mathrm{D}} / \mathrm{V}_{\mathrm{T}}$ indicate the development of ventilation-perfusion $(\dot{\mathrm{V}} / \dot{\mathrm{Q}})$ mismatch, increased dead space ventilation, an increase in intrapulmonary shunt and interstitial oedema. Similar findings have been reported in patients with pulmonary embolism. ${ }^{29}$ Hence this study is the first to measure the local response of the right ventricular free wall to increased right ventricular afterload in a "physiological setting".

Embolisation was terminated at a peak pulmonary artery pressure of $40 \mathrm{~mm} \mathrm{Hg}$ in order to avoid global cardiac failure. ${ }^{31}$ As a result, cardiac index remained unchanged during the whole study (table I) allowing measurements to be made in stable haemodynamic conditions. 
CONTRACTION PATTERN OF THE RIGHT VENTRICLE Segment lengths and local preload

The main finding in our experiments was that acute pulmonary microembolisation resulted in divergent changes in end diastolic fibre lengths depending upon the region in the myocardium: while end diastolic length was increased by microembnlisaton in the right ventricular inflow tract, it was decreased in the outflow tract. Since the end diastolic fibre length is a preferred and valid measure of preload in either ventricle, ${ }^{89}$ our results suggest that acute pulmonary microembolisation induces regionally different changes in local preload within the canine right ventricular free wall.

In closed chest dogs, Santamore et al ${ }^{26}$ have investigated the influence of increased right ventricular afterload on end diastolic segment length in both the inflow and outflow tracts of the right ventricle. As in the present study, end diastolic length in the inflow tract was found to be increased after pulmonary artery constriction. These authors did, however, observe that end diastolic segment length was unchanged in the outflow tract, in contrast to our present results. This may be explained by the higher right ventricular afterload in Santamore's study. This view would explain our finding that the two animals in which the outflow tract segment length had increased were those reaching the highest level of pulmonary hypertension after embolisation. On the other hand, segment length was found to be already reduced in the outflow tract at $A P M E_{1}$, suggesting that a decrease in segment length only occurs at moderate levels of pulmonary hypertension, while at a high pulmonary artery pressure the outflow tract becomes redistended.

Several sources of error have to be considered when assessing end diastolic segment length. As in other studies, ${ }^{16} 2532$ end diastole has been defined for both regions as the beginning of the upstroke of $d R V P / d t$. Under normal conditions, relaxation of the right ventricular inflow tract precedes relaxation of the outflow tract; ${ }^{102326}$ to rule out the possibility that incomplete relaxation of the outflow tract (ie, underestimation of true end diastolic segment length in comparison with the inflow tract) has influenced our results, we have additionally analysed maximal segment length. Since changes of diastolic and maximal lengths diverged in one experiment only (fig 2), a systematic error in assessing end diastolic length at the beginning of $\mathrm{dRVP} / \mathrm{dt}$ upstroke can be excluded.

In order not to compromise the ability of the heart to adapt to acute pulmonary microembolisation and so as not to alter the physiological time course of right ventricular electrical activation ${ }^{33}$ and contraction, ${ }^{16}$ heart rate was not controlled. The increase in heart rate by $35 \%$ at $\mathrm{APME}_{2}$ might therefore have caused incomplete relaxation of the right ventricular outflow tract and thereby a decrease of segment length in this region. Since, however, all measurements were performed simultaneously, changes in heart rate should have affected segment length in the same way in both regions of the right ventricular free wall. Thus tachycardia is not likely to explain the opposite changes of end diastolic segment length in the inflow and outflow tracts.

\section{Segment shortening}

The ultrasonic crystals were implanted in the longitudinal axis of the inflow and outflow tracts because in this direction segment shortening is maximum in both regions. ${ }^{28} \mathrm{At}$ control, maximal shortening was $15.0 \%$ in the outflow tract and $9.2 \%$ in the inflow tract. Higher values have been described in open chest dogs by Raines et $a l^{23}(21 \%$ and $13 \%$, respectively), Priebe ${ }^{25}(19.6 \%$ and $18.9 \%)$ and Morris et $a l^{17}(21 \%$ in the inflow tract). Because segment movement is increased in pericardectomised heart $\mathrm{s}^{28}$ the former results cannot be compared directly with the present findings. However, our results compare favourably with data obtained by means of implanted radio-opaque markers in anaesthetised, closed chest dogs: Meier et $a l^{28}$ reported segment shortening to be $12.2 \%$ in the right ventricular outflow tract and $11.7 \%$ in the inflow tract of acutely instrumented dogs. Slightly higher values ( $16.1 \%$ and $13.8 \%$, respectively) have been found by Santamore et al in chronically instrumented dogs. ${ }^{26}$

Our results provide evidence that segment shortening is affected differently by acute pulmonary microembolisation in right ventricular inflow and outflow tracts. While shortening was not affected in the inflow tract, it decreased in the outflow tract. Since the degree of right ventricular free wall shortening is a linear function of end diastolic segment length ${ }^{2}$ the decrease in outflow tract shortening could be explained by the concurrent fall in end diastolic segment length. The functional consequence of the discrepancy in inflow tract and outflow tract shortening is emphasised by the fact that with an increased end diastolic segment length, less shortening is needed to eject the identical volume. Therefore, outflow tract contraction substantially decreased not only with respect to absolute amplitude of contraction but even more so with regard to efficiency of contraction. In contrast, inflow tract contraction - starting from an increased end diastolic segment length - has presumably been more efficient in microembolisation as compared to control despite unchanged systolic shortening.

These results are supported by the work of Morris et $a l,{ }^{17}$ who could not show a substantial decrease in inflow tract shortening subsequent to pulmonary artery constriction in open chest dogs. Accordingly, in a similar model of pulmonary artery constriction in closed chest dogs, Santamore et $a l^{26}$ reported shortening to be decreased in the outflow tract without being significantly altered in the inflow tract.

However, due to the peristaltic pattern of right 
ventricular free wall contraction, ${ }^{24}$ care has to be taken when systolic segment shortening in the inflow and outflow tracts is compared directly. According to Priebe, ${ }^{25}$ we assessed systolic shortening at exactly the same time (peak negative $\mathrm{dRVP} / \mathrm{dt}$ ) in both the inflow tract and the outflow tract and calculated systolic segment shortening as end diastolic minus systolic segment length. Since the right ventricular outflow tract is known to shorten and to lengthen later than the inflow tract, ${ }^{24}$ this technique may underestimate active contraction of the outflow tract as compared to the inflow tract. In order to evaluate this potential source of error, right ventricular outflow tract shortening has been recalculated by subtracting minimal segment length (instead of systolic segment length) from end diastolic segment length: outflow tract shortening was now found to be $14.8 \%, 11.3 \%$ and $6.5 \%$ at control, $A P M E_{1}$ and $A P M E_{2}$ respectively $(p<0.01$ between each measurement), and was thus $\approx 3 \%$ higher than if calculated as end diastolic minus systolic segment length (see table IV). However, there were no major differences with respect to the absolute changes of outflow tract shortening subsequent to microembolisation and no difference with respect to the levels of significance. This suggests that our finding of a decreased outflow tract contraction due to microembolisation holds true independent of the method used for calculation of systolic outflow tract shortening.

No definite explanation can be given at the moment as to the mechanisms causing the regionally opposite changes in local right ventricular preload and segment shortening after microembolisation. The well known disparity between the right ventricular inflow and outflow tracts with respect to fibre architecture ${ }^{20}$ and fibre compliance ${ }^{8}$ might account for quantitatively different changes in diastolic segment length, but hardly explains opposite changes of local preload within the right ventricular free wall following microembolisation. Since functional signs of right ventricular inflow tract ischaemia were not observed (eg, reduced segment shortening, protosystolic segment elongation), it seems unlikely that the increase in the end diastolic fibre length after microembolisation was caused by ischaemic myocardial dilatation.

It seems more likely that the inhomogeneous sympathetic innervation of the right ventricular free wall ${ }^{112034}$ and the resulting regionally different degrees of sympathetic activation of right ventricular myocardium have been responsible for the discrepant changes in local preload and local segment shortening in the inflow and outflow tracts subsequent to microembolisation.

Dynamic pattern of right ventricular contraction (PL
loops) As previously described, ${ }^{12}$ the configuration of the right ventricular pressure-length loops was found to be oval or triangular under control conditions. After acute pulmonary microembolisation, loops assumed a rectangular shape with peak right ventricular pressure coinciding with minimum segment length (fig 4). Since inflow tract shortening is closely correlated with changes of right ventricular volume, ${ }^{235}$ right ventricular ejection obviously does not continue beyond peak right ventricular pressure when afterload is elevated. Thus in acute pulmonary microembolisation right ventricular dynamic contraction very much resembles left ventricular contraction. ${ }^{2} 18$

As an explanation of this phenomenon, an "activation" of the Starling mechanism subsequent to increased right ventricular free wall distension has been proposed. ${ }^{36}$ In the present study, however, rectangular PL loops occurred not only in the inflow tract, but also in the outflow tract despite end diastolic segment length being reduced by microembolisation in this region. This indicates that mechanisms other than increased local preload (eg, sympathoadrenergic stimulation) have caused the outflow tract contraction pattern after microembolisation to resemble the normal left ventricular contraction pattern.

\section{CLINICAL IMPLICATIONS}

The tenet that fibre tension is equally affected throughout the myocardial wall by changes in afterload does not apply for the right ventricle after acute pulmonary microembolisation because regionally divergent changes of local right ventricular preload have been encountered within the right ventricular free wall.

This finding has consequences for the interpretation of global measures of right ventricular preload. In the schematic cross section of the heart (fig 5), the diastolic segment length of the right ventricular inflow and outflow tracts is indicated by the distance of the ultrasonic crystals. The diagram on the left depicts the right ventricle in its normal configuration. In pulmonary embolism (diagram on the right), the reduction in diastolic segment length in the outflow

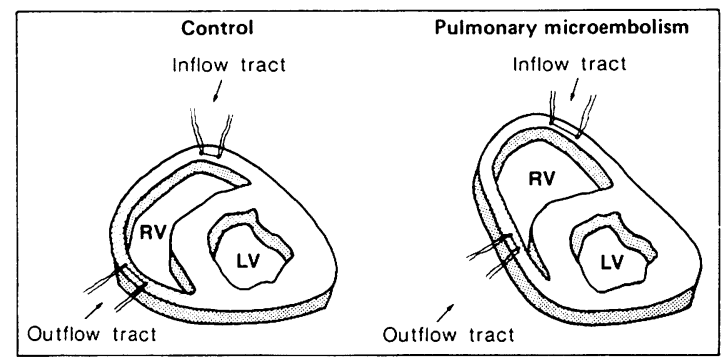

Figure 5 The change of right ventricular $(R V)$ geometry following pulmonary microembolism is shown in this scheme of a cross section of the heart (for further explanation see Discussion). 
tract coincides with a dilatation of the inflow tract and thereby results in an altered configuration of the right ventricle. Comparison of the graphs reveals, however, that the change in right ventricular geometry is not necessarily accompanied by a change in end diastolic volume. Nevertheless, the functional state of the myocardial fibres may have improved or worsened considerably in this situation.

Our findings may have implications for the clinical evaluation of right ventricular function in patients presenting with an acute increase in pulmonary vascular resistance. First, global right ventricular performance may be altered in these patients as a result of a change in right ventricular geometry despite unchanged end diastolic volume. Second, right ventricular inflow tract dilatation may already be present without being reflected by a high end diastolic volume. In these patients, even a minor increase in end diastolic volume could result in acute overdistension of the inflow tract and thereby depress global right ventricular performance and cardiac output.

Third, when estimating right ventricular end diastolic volume by echocardiographic measurement of the septal to right ventricular free wall distance, the direction of the ultrasonic beam has to be taken into account: depending on whether septal to inflow tract or septal to outflow tract distance is assessed, a different end diastolic volume may be calculated if acute pulmonary hypertension is present. It should be noted, however, that our results apply to the intact right ventricle; the effects of pulmonary microembolisation on a compromised right ventricular myocardium might be more pronounced and remain to be clarified.

\section{CONCLUSION}

In conclusion, our study has shown substantial differences between the inflow and outflow tract of the primarily intact canine right ventricle with regard to changes in local preload and segment shortening induced by pulmonary microembolisation. Indices of global right ventricular preload do not reflect these local differences and therefore may be misinterpreted. Regardless of the opposite changes of local preload, however, similar changes in the dynamic pattern of contraction (PL loops) occur in both regions following acute pulmonary microembolisation: the triangular or oval PL loops become rectangular in shape, indicating that under conditions of an acutely elevated right ventricular afterload, the local dynamic contraction of both the inflow tract and the outflow tract closely resembles the contraction pattern of the left ventricle.

The authors thank Roswitha Schwarz, Jutta Schulte, Karin Sonnenberg and Heidrun Voigt for their expert technical assistance and Dr sc hum Heinrich Zeintl for developing the computer evaluation system.

This work was supported by Deutsche Forschungsgemeinschaft grant SFB 320/C3.
I Maughan WL, Shoukas AA, Sagawa K, Weisfeld $M L$. Instantaneous pressure-volume relationship of the canine right ventricle. Circ Res 1979;44:309-15.

2 Morris JJ, Pellom GL, Murphy CE, Salter DR, Goldstein JP, Wechsler AS. Quantification of the contractile response to injury: assessment of the work length relationship in the intact heart. Circulation 1987;76:717-27.

3 Brunet F, Dhainaut JF. Right ventricular performance during mechanical ventilation in ARDS. In: Vincent JL, ed. Update in intensive care and emergency medicine, vol 5. Berlin: Springer, 1988:219-26.

4 Qvist J, Mygind T, Crottogini A, et al. Cardiovascular adjustments to pulmonary vascular injury in dogs. Anesthesiology 1988:68:341-9.

5 Sibbald WJ, Driedger AA, Myers ML, Short AIK, Wells GA. Biventricular function in the adult respiratory distress syndrome. Hemodynamic and radionuclide assessment with special emphasis on right ventricular function. Chest 1983;84:126-34.

6 Weber KT, Janicki JS, Shroff SG, Likoff MJ, Sutton MGJ. The right ventricle: physiologic and pathophysiologic considerations. Crit Care Med 1983;11:323-8.

7 Dhainaut JF, Brunet F, Villemant D. Monitoring of right ventricular performance in the ICU. In: Vincent JL, ed. Update in intensive care and emergency medicine, vol 3. Berlin: Springer, 1987:336-41.

8 Leyton RA, Spotnitz HM, Sonnenblick EH. Cardiac ultrastructure and function: sarcomeres in the right ventricle. A m F Physiol 1971;221:902-10.

9 Sibbald WJ, Driedger AA. Right ventricular function in acute disease states: pathophysiological considerations. Crit Care Med 1983;11:339-45.

10 Hurford WE, Zapol WM. The right ventricle and critical illness: a review of anatomy, physiology, and clinical evaluation of its function. Intensive Care Med 1988;14:448-57.

11 Pace JB, Keefe WF, Armour JA, Randall WC. Influence of sympathetic nerve stimulation on right ventricular outflow-tract pressures in anesthetized dogs. Circ Res 1969;24:397-407.

12 Pinsky MR. Assessment of right ventricular function in the critically ill: fact, fancy, and perspectives. In: Vincent JL, ed. Update in intensive care and emergency medicine, vol 8. Berlin: Springer, 1989:518-23.

13 Heimisch W, Hagl S, Gebhardt $\mathrm{K}$, Meisner $\mathrm{H}$, Mendler $\mathrm{N}$, Sebening F. Direct measurement of cyclic changes in regional wall geometry in the left ventricle of the dog. Innov Tech Biol Med 1981;2:487-501.

14 Holt JP, Rhode EA, Kines H. Ventricular volumes and body weight in mammals. Am $\mathcal{F}$ Physiol 1968;215:704-15.

15 Rossing RG, Cain SM. A nomogramm relating $\mathrm{PO}_{2}, \mathrm{pH}$, temperature and hemoglobin saturation in the dog. $\mathcal{F} \mathrm{Appl}$ Physiol 1966;21:195-201.

16 Pouleur H, Lefevre J, van Mechelen H, Charlier AA. Free-wall shortening and relaxation during ejection in the canine right ventricle. Am F Phvsiol 1980;239:601-13.

17 Morris JJ, Pellom GL, Hamm DP, Everson CT, Wechsler AS. Dynamic right ventricular dimension. Relation to chamber volume during the cardiac cycle. I Thorac Cardiovasc Surg 1986;91:879-87.

18 Akaishi M, Weintraub WS, Schneider RM, Klein LW, Agarwal JB, Helfant RH. Analysis of systolic bulging. Mechanical characteristics of acutely ischemic myocardium in the conscious dog. Circ Res 1986;58:209-17.

19 Zwissler B. Forst H, Ishii K, Messmer K. A new experimental model of ARDS and pulmonary hypertension in the dog. Res Exp Med 1989;189:427-38.

20 Armour JA, Pace JB, Randall WC. Interrelationship of architecture and function of the right ventricle. Am F Physiol 1970;218:174-9.

21 Keith A. Fate of the bulbus cordis in the human heart. Lancet 1924;ii: 1267-73.

22 March HW, Ross JK, Lower RR. Observations on the behavior of the right ventricular outflow tract, with reference to its developmental origins. Am F Med 1962;32:835-45.

23 Raines RA, LeWinter MM, Covell JW. Regional shortening patterns in canine right ventricle. Am $\mathcal{F}$ Physiol 1976;231:1395-400.

24 Foex P. Right ventricular contraction. In: Vincent JL, ed. Update in intensive care and emergency medicine, vol 3. Berlin: Springer, 1987:72-80.

25 Priebe HJ. Efficacy of vasodilator therapy in canine model of acute pulmonary hypertension. Am f Physiol 1988;255:1232-9. 
26 Santamore WP, Meier GD, Bove AA. Effects of hemodynamic alterations on wall motion in the canine right ventricle. $A m \mathcal{F}$ Physiol 1979;236:254-62.

27 Calvin JE, Baer RW, Glantz SA. Pulmonary artery constriction produces a greater right ventricular afterload than lung microvascular injury in the open chest dog. Circ Res 1985;56:40-56.

28 Meier GD, Bove AA, Santamore WP, Lynch PR. Contractile function in canine right ventricle. $A m \quad \mathcal{F}$ Physiol 1980;239:794-804.

29 Moser KM. Pulmonary embolism: state of the art. Am Rev Respir Dis 1977;115:829-52.

30 Zapol WM, Snider MT. Pulmonary hypertension in severe acute respiratory failure. $N$ Engl F Med 1977;296:476-80.

31 Hurford WE, Barlai-Kovach $M$, Strauss HW, Zapol WM, Lowenstein E. Canine biventricular performance during acute progressive pulmonary microembolization: regional myocardial perfusion and fatty acid uptake. $\mathcal{F}$ Crit Care 1987;2:270-81.
32 Forst H, Racenberg J, Messmer K. Lokale und globale Kontraktilität des rechten Ventrikels bei Ischämie seiner freien Wand. Anaesthesist 1988;37:356-65.

33 Freud GE, Stern MC, Watson H, Durrer D. Activation of the hypertrophic right ventricle in the dog. Cardiovasc Res 1975;9:302-13.

34 Tobin JR, Blundell PE, Goodrich RG, Swan HJC. Induced pressure gradients across infundibular zone of right ventricle in normal dogs. Circ Res 1965;16:162-73.

35 Hamm DP, Everson CT, Freedman BM, Pellom GL, Christian C, Wechsler AS. The passive right ventricular volume-dimension relationship in the isolated canine heart. Surg Forum 1984;35:266-8.

36 Piene H, Covell JW. Local auxotonic systolic force and work in canine right ventricular free wall. $A m \mathcal{J}$ Physiol 1983;244:186-93. 